University of Nebraska - Lincoln

DigitalCommons@University of Nebraska - Lincoln

Management Department Faculty Publications

Management Department

2008

\title{
Leadership efficacy: Review and future directions
}

\author{
Sean T. Hannah \\ United States Military Academy, USA, sean.hannah@usma.edu \\ Bruce Avolio \\ University of Nebraska - Lincoln, bavolio@u.washington.edu \\ Fred Luthans \\ University of Nebraska - Lincoln, fluthans1@unl.edu \\ Peter D. Harms \\ University of Nebraska - Lincoln, pharms@gmail.com
}

Follow this and additional works at: https://digitalcommons.unl.edu/managementfacpub

Part of the Management Sciences and Quantitative Methods Commons

Hannah, Sean T.; Avolio, Bruce; Luthans, Fred; and Harms, Peter D., "Leadership efficacy: Review and future directions" (2008). Management Department Faculty Publications. 5.

https://digitalcommons.unl.edu/managementfacpub/5

This Article is brought to you for free and open access by the Management Department at DigitalCommons@University of Nebraska - Lincoln. It has been accepted for inclusion in Management Department Faculty Publications by an authorized administrator of DigitalCommons@University of Nebraska - Lincoln. 
Published in The Leadership Quarterly (2008), doi:10.1016/j.leaqua.2008.09.007

Copyright @ 2008 Published by Elsevier Inc. Used by permission.

http://www.elsevier.com/locate/leaqua

Published online October 19, 2008.

\title{
Leadership efficacy: Review and future directions
}

\author{
Sean T. Hannah, ${ }^{*}$ Bruce J. Avolio, ${ }^{\dagger}$ Fred Luthans, ${ }^{\ddagger}$ and P. D. Harms ${ }^{\ddagger}$ \\ * Department of Behavioral Sciences and Leadership, \\ United States Military Academy, USA \\ $\dagger$ Department of Management and Organization, Foster Business School, \\ University of Washington, USA \\ $\ddagger$ Department of Management, College of Business Administration, \\ University of Nebraska-Lincoln, USA \\ Corresponding author - S. T. Hannah, tel 845 496-8747, email Sean.hannah@usma.edu
}

\begin{abstract}
The concept of leader efficacy has received relatively little attention in the leadership literature. This is somewhat surprising given that effective leadership requires high levels of agency (i.e., deliberately or intentionally exerting positive influence) and confidence. This review uses existing theory and research on leader efficacy as a point of departure for proposing an expanded and multi-level framework for understanding the domain of leadership efficacy that includes leader, follower, and collective efficacies. The primary goals are to provide a conceptual framework to stimulate future theory and research on building efficacious leadership and to understand how such leadership develops and has implications for effective performance.
\end{abstract}

Keywords: leader efficacy, agency, collective efficacy, means efficacy, leadership

Today's leaders face unprecedented challenges as organizations struggle to adapt to ever-accelerating rates of change both internally and with the external environment in which they are embedded. Such change challenges not only the knowledge, skills and abilities of leaders, but perhaps even more important, the self-conceptualizations of their leadership capabilities and psychological resources to meet the ever increasing demands of their roles (Avolio and Luthans, 2006; Hooijberg et al., 1997; Lord and Hall, 2005). Given such complex challenges, it would be hard to imagine anyone following or being positively influenced by leaders who do not welcome or accept such challenges. Yet, how much do we, and should we, know about such leadership efficacy? The answer to this question is the purpose of this review.

Leadership efficacy is a specific form of efficacy associated with the level of confidence in the knowledge, skills, and abilities associated with leading others. It can thus be clearly differentiated from confidence in the knowledge, skills, and abilities one holds associated with other social roles such as a teacher (i.e., teacher efficacy) or statesman (i.e., political efficacy).

We argue that the current conditions require leaders to continually "step up" to meet complex challenges and to have the requisite agency to positively influence their followers and the organization's culture, climate, and performance. To mobilize groups toward collective performance, leaders have to both exercise high levels of personal agency and create similar levels of agency in those individuals they are leading by proxy (Bandura, 2000).

Central to leadership and its development, Bandura (1997) states that efficacy is the most pervasive among the mechanisms of agency and provides a foundation for all other facets of agency to operate. Efficacy's relevant and comprehensive nature in meeting today's leadership challenges is captured by Bandura \& Locke's (2003, p. 87) statement that efficacy beliefs "affect whether individuals' think in self-enhancing or self-debilitating ways, how well they motivate themselves and persevere in the face of difficulties, the quality of their well-being and their vulnerability to stress and depression, and the choices they make at important decision points."

Hannah, Woolfolk, \& Lord (in press) and Hannah \& Luthans (2008) have recently proposed that positive psychological states such as efficacy directly promote effective leader engagement, flexibility and adaptability across the varying 
challenges characterizing complex organizational contexts. This is because higher levels of self-efficacy provide the internal guidance and drive to create the agency needed to pursue challenging tasks and opportunities successfully (Carver and Scheier, 1998; Cropanzano et al., 1993; Lord and Brown, 2004; Mischel and Shoda, 1998; Shamir et al., 1993). Beyond this we argue that the strategy for developing leadership should consider leaders' and followers' efficacies for taking on the challenges of development and performance. Our definition of such leaders' (followers') efficacy is the following:

Leaders' (followers') beliefs in their perceived capabilities to organize the positive psychological capabilities, motivation, means, collective resources, and courses of action required to attain effective, sustainable performance across their various leadership roles, demands, and contexts.

In this review, we first provide a multi-level framework for differentiating and discussing the interactions between leader efficacy and leadership efficacy. Second, we summarize and integrate the relatively limited body of knowledge on leader efficacy and related areas of efficacy research (e.g., from education, clinical and social psychology, and organizational behavior). Finally, we make the case for advancing a body of leadership efficacy research that incorporates follower and collective efficacy and offer directions to guide these efforts toward a more practical focus on how such efficacy can be developed. Specifically, we propose four areas of needed research:

To advance leader efficacy:

1. Investigating the hierarchical structuring of a leader's efficacy beliefs which we propose is comprised of general efficacy, means efficacy, and various domains of specific self-efficacy, as well as the interactions between these various forms of efficacy in facilitating effective performance.

2. Advancing a deeper understanding of how efficacy develops and operates within leaders' self-systems and influences subsequent cognition, affect and behavior.

To advance leadership efficacy:

3. Taking a multi-level approach toward understanding the emergence of efficacy in organizations, including individual (leader and follower), team/collective and organizational levels.

4. Based on our expanded conceptualization of leadership efficacy; making proposals to refine the antecedents to and processes of leadership efficacy development.

\section{Differentiating leader efficacy and leadership efficacy}

To meet the call of previous yearly review issues of $L Q$ we will focus on the multi-level effects of leadership efficacy (e.g., see [Hunt, 2005; Yammarino et al., 2005). Also, we will answer the call for a greater focus on context for leadership in this review (Hunt, 2006; Osborn et al., 2002; Porter and McLaughlin, 2006).

While there has been research examining the direct effects of leaders' agency on follower efficacy and performance, most of the literature has failed to take into account the broader context and multiple sources of influence of leadership on follower efficacy and performance (van Knippenberg, van Knippenberg, De Cremer, \& Hogg, 2004). Addressing the need to better incorporate context and levels into leadership research, Day (2001) made clear the theoretical distinctions between individual leader development and collective leadership development. Similarly, distinctions can be made between leading (behaviors of individual leaders) and leadership, which we conceptualize as the emergent positive influences occurring in a group of which the leader is a part. We suggest there is potentially great value in building a more comprehensive understanding of the contribution of leader efficacy in building collective leadership efficacy. By pursuing this linkage, we intend to connect the limited literature on leader efficacy with the larger body of research on organizational behavior efficacy to facilitate the modeling of efficacy formed through the interactions between leaders, followers and groups. Our literature review surprisingly did not uncover any articles addressing leadership efficacy.

Organizational researchers have widely explored efficacy constructs such as self-efficacy (Holden, 1991; Multon et al., 1991; Stajkovic and Luthans, 1998), general efficacy (Chen, Gully, \& Eden, 2001), means efficacy (Eden, 2001; Eden and Sulimani, 2002), and forms of collective or team efficacy (Gully et al., 2002; Prussia and Kinicki, 1996; Tasa et al., 2007). This body of research has clearly demonstrated how each of these types of efficacy are related to desired performance outcomes. We posit that linking leadership to these constructs may advance our understanding of how to enhance collective agency and performance. Therefore, in a later section we will build out a multi-level examination of leadership efficacy with the intent of linking leader, follower and collective efficacies. By doing so we hope to bridge the recent focus on positive organizational behavior (Luthans et al., 2007; Luthans and Youssef, 2007) with the more macro focus of positive organizational scholarship (Cameron and Caza, 2004; Cameron et al., 2003). For example, when leaders and followers share a positive view of their abilities to constructively influence each other, and then support each other and perform well, we suggest that unique organizational cultures may emerge where these contextual factors not only shape leadership efficacy, but will also be impacted by leadership efficacy over time.

Figure 1 provides a graphic portrayal of our proposed theoretical framework. As shown, we link the reciprocal influence of leader efficacy with the efficacy of each follower, as well as between the leader, each follower, and the collective. In other words, we propose that these leader and follower causal links build over time collective efficacy, which in turn helps drive and sustain effective performance outcomes. Ultimately, when groups form such a shared mental model of their collective efficacy, the resulting beliefs promote collective agency and increased collective performance. 


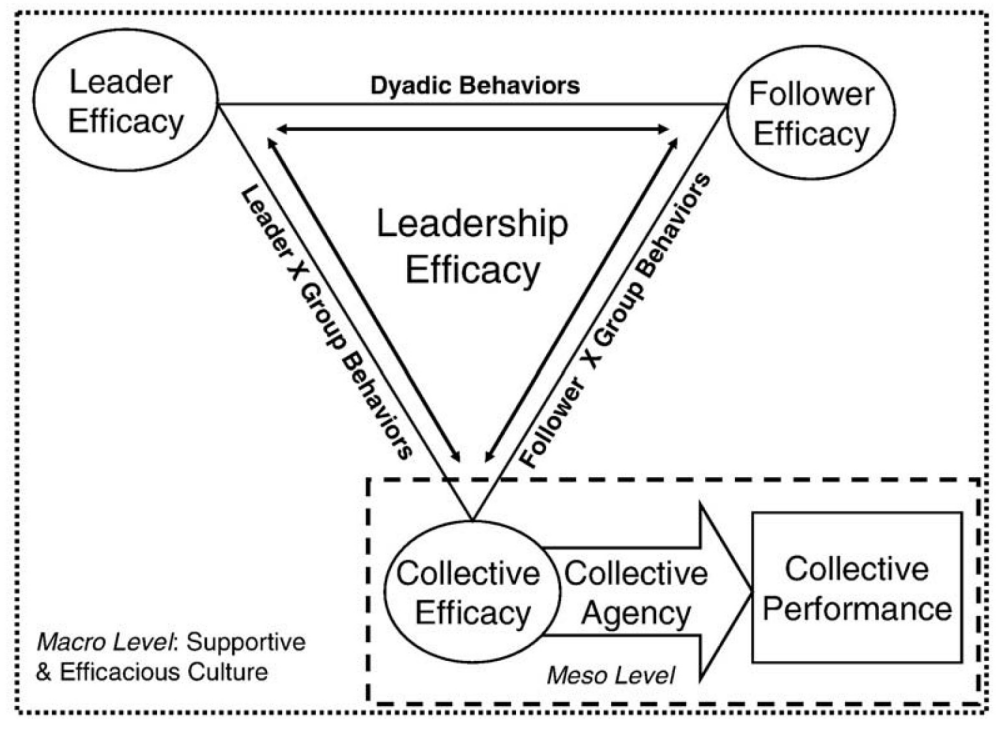

Figure 1. Framework for leader efficacy and leadership efficacy.

\section{Foundations of leader efficacy research}

Using Figure 1 as our point of departure and roadmap, we begin our review by focusing on the upper left portion and present an overview and synthesis of existing leader efficacy (not leadership efficacy) research in the areas of self, general, and means efficacies. Table 1 summarizes the relatively limited existing body of empirical articles on both leader efficacy and the sub-components of leader efficacy. Table 1 addresses the aspects of leader efficacy that have been explored in prior empirical research, the nature of that research, and the major findings relevant to the leader efficacy domain. Specifically, in this section we focus our discussion on leader self-efficacy and will transition in the following section to building out and offering propositions toward a multi-level theory of leadership efficacy.

It should be noted at the outset that the term self-confidence (not necessarily self-efficacy) has been commonly proposed as a critical leader attribute in previous literature reviews (House and Aditya, 1997; Locke, 1991; Yukl and Van Fleet, 1992) and case studies (Bennis and Nanus, 1985; Kaplan, 1991), as well as in the popular leadership literature (George, 2003; Kouzes and Posner, 1993). For example, Howell \& Shamir (2005) noted that of all the attributes leaders need to convey, confidence is always critically associated with effective leadership. Although Bandura avoids usage of the more popular, but less precise, term of confidence, except when using it as a descriptor of areas such as faulty selfappraisals (e.g., "overconfidence", or "underconfidence", see Bandura, 1997, pp. 10-11), we will use, as does most of the leadership literature, confidence and efficacy interchangeably. However, we prefer the term efficacy to align our propositions with the most relevant theories and research.

Confidence or efficacy has not only been proposed as a central component of the recently emerging literature concerning positive organizational behavior (Luthans, 2002; Luthans and Youssef, 2007; Luthans et al., 2007), but it has also been directly tied to authentic leadership and its development (Avolio and Luthans, 2006; Luthans and Avolio, 2003). Therefore, we suggest that advancing a more robust conceptualization of what constitutes leader efficacy would seem to have great potential to furthering our understanding of leader emergence, engagement, development, and performance from both a theoretical and a practical perspective.

\subsection{View of leader self-efficacy}

Self-efficacy has been the most widely studied form of efficacy and has received considerable attention in the fields of cognitive and social psychology through extensive theory building and research by Bandura (1997) and others (e.g., Maddux, 1995). Wood \& Bandura (1989a, p. 48) define self-efficacy as "beliefs in one's abilities to mobilize the motivation, cognitive resources, and courses of action needed to meet situational demands." Research has demonstrated strong positive relationships between self-efficacy and various criteria of human performance in organizations (for meta-analyses see: [Holden, 1991; Multon et al., 1991; Stajkovic and Luthans, 1998). For example, in their meta-analysis of 114 studies, Stajkovic \& Luthans (1998) reported an average weighted correlation of .38 between self-efficacy and work-related performance.

Despite the call by Gist (1989) to apply this potent construct to leadership research, there have been only limited theory-building contributions linking efficacy to leaders (Chemers, 1997; Hollenbeck and Hall, 2004; Luthans et al., 2002; Kirkpatrick and Locke, 1996; McCormick, 2001; Popper et al., 2004; Prussia et al., 1998; Rafferty and Griffin, 2006). In addition, there are only a small number of empirical studies on leader efficacy (Chan and Drasgow, 2001; Chemers et al., 2000; Finn et al., 2007; Hannah, 2006; Hendricks and Payne, 2007; Hoyt, 2005; Kane et al., 2002; Larson and Borgen, 2006; McCormick, 1999; McCormick et al., 2002; Mellor et al., 2006; Murphy and Ensher, 1999; Onglatco et al., 1993; Paglis and Green, 2002; Semandar et al., 2006; Singer, 1989; Singer, 1991; Taggar and Seijts, 2003). The same is true of empirical 
Table 1. Leader self-efficacy

\begin{tabular}{lll}
\hline Leader self-efficacy & Target focus & Methods \\
BANDURA \& WOOD (1989) & Tested whether perceived control- & Business students participated in \\
& lability and stringency of perfor- & a multi-stage experimental task \\
& mance standards impacted man- & with feedback. Participants were \\
& agerial efficacy in a simulated & assessed for managerial efficacy at \\
& organization. & each stage.
\end{tabular}

Chan \& Drasgow (2001)

Chemers et AL. (2000)

FINN ET AL. (2007)

HENDRICKS \& PAYNE (2007)

HoYT (2005)

Luthans \& Peterson (2002)

McCoRMick (1999)

MCCORMICK ET AL. (2002)

Mellor et AL. (2006)

Leader self-efficacy
Tested a model of the relationship between leader characteristics and leader behavior.

Examined the effects of LSE and on leadership and other performance outcomes.

Tested the effects of an executive coaching program on the development of various characteristics associated with leadership.

Examined LSE as a mediator of the trait-leadership performance relationship.

Undergraduate students formed groups of 4 with a leader to perform a manufacturing task.

A two-part study of military cadets that assessed LSE in cadet leaders. Cadets were later rated for leadership potential and performance by experts and observers.

A yearlong transformational leadership training program was conducted at a large public sector organization. One group of executives received executive coaching after

Examined the role of leader efficacy as a moderator of leadership identification in response to gender stereotypes.

Investigated the relationship between a leader's efficacy beliefs, follower engagement, and leader effectiveness.

Examined the influence of sex-role identity and goal orientation on the development of LSE during a training intervention.

Tested the hypotheses that LSE would be associated with both more previous experiences in leadership roles and with more attempts to assume leadership roles.

Assessed the effects of verbal persuasion and gender-matching on leadership self-efficacy in a union setting.
Female university students filled out surveys of LSE and leadership identification either in male-asleader stereotype conditions or not.

Surveyed managers in addition to their peers and subordinates. Ratings of LSE were made by leaders while followers rated engagement. Leaders, followers, and peers all rated perceived manager effectiveness.

Student volunteers participated ei ther in 15-week leadership training or control classes and were assessed for LSE, sex-role identity, and goal orientation before and after the intervention.

University students rated their own LSE, the number of leadership experiences they had in the past, and how often they had sought to be a group leader when given the opportunity

Assessed members of a union in the eastern U.S. for efficacy to serve as a shop steward, whether or not they had been encouraged to take a leadership role in the union by a current steward, and whether that person was the same gender as them.

\section{Results}

Prior performance predicted managerial efficacy beliefs. Managerial efficacy was a significant positive predictor of future performance.

Participants who believed that organizations are controllable maintained their efficacy levels across trials while those who believed that organizations are difficult to control displayed low levels of managerial efficacy.

Leader self-efficacy was predicted by extraversion, conscientiousness, openness to experience, and prior experience. LSE partially mediated the effects of traits on affective-identity and social normative motivation to lead. LSE was also associated with higher ratings of leadership potential $(r=.17)$. This study illustrates how efficacy for leadership is developed from both internal and external sources and how LSE impacts leadership orientation.

LSE correlated significantly with instructor ratings of leadership potential $(r=.48)$, overall officer ratings during a training camp $(r=.47)$, peer-ratings of leadership effectiveness $(r=.58)$, and scores on two squad leader assessment courses ( $r \mathrm{~s}=.30, .47)$. LSE was not significantly related to non-leadership performance outcomes indicating that its effects were specific to the leadership domain.

After experiencing executive training, the executives in the experimental condition had higher scores on transformational leadership efficacy $(r=.45)$ and a variety of other outcomes. Further, those executives in the experimental session were also rated as more transformational by their team members $(r=.39)$. This indicated that not only is LSE trainable but that it manifests itself as positive leadership behaviors.

LSE partially mediated the relationship between goal orientation and affective-identity and social normative motivation to lead $(r=.38)$ after controlling for the Big Five personality traits. LSE was also significantly correlated with subjective group outcomes $(r=.29)$, but not with objective group performance $(r=.12)$.

Higher levels of leader efficacy were related to higher levels of leadership identification when under negative stereotype threat.

LSE was significantly related to different ratings of effectiveness ( $r$ s $=.24-.47)$ and to measures of employee engagement $(r s=.16, .21)$. Results indicate that LSE is a partial mediator of the relationship between employee engagement and managerial effectiveness.

LSE was highly stable over time $(r=.80)$ and was largely unaffected by the training intervention. Having a lower masculinity sexrole was significantly related with change $(r=-.24)$.

LSE was positively correlated with both prior leadership experience $(r=.41)$ and with attempting to assume leadership positions $(r=.60)$.

Being encouraged to serve as a shop steward was associated with higher efficacy for leadership $(r=.32)$. This effect was augmented when the gender was congruent between the leader and follower. 
Table 1. Leader self-efficacy (continued)

\begin{tabular}{lll}
\hline Leader self-efficacy & Target focus & Methods \\
MURPHY \& ENSHER (1999) & Investigated the contribution of & Studied interns at a media com- \\
& team member characteristics in the & pany and their supervisors. Qual- \\
development of leader-member & ity of relationships and charac- \\
& exchange. & teristics assessed twice over an \\
& 8-week period.
\end{tabular}

ONGLATCO ET AL. (1993)

Paglis \& GReEN (2002)

ROBERTSON \& SADRI (1993)

SEMANDAR ET AL. (2006)

WOOD \& BANDURA $(1989$ A

Subdomains of leadership selfefficacy

HANNAH (2006)

JENKINS (1994)

SINGER (1989)
Explored the relationship between managerial efficacy and performance in a non-western setting.

Tested a theoretical model of LSE and the relationship of LSE to leadership attempts.

To test the relationship of managerial self-efficacy to supervisor ratings of performance.

To establish the relative validity of leader efficacy, self-monitoring, emotional intelligence, and political skill in predicting managerial performance.

Tested whether induced conceptions of ability as either a stable or developable entity would affect self-regulatory mechanisms governing performance.

Developed and tested a model of agentic leadership efficacy (ALE) in addition to studying the development of efficacy beliefs. ALE was subdivided into means, action, and thought/self-motivation components in addition to transactional and transformational elements.

Assessed the role of managerial and means efficacy on organizational compliance to laws.

Studied the relationship between leadership aspirations, LSE, and attributions of effective leadership.
Managers in Singapore were assessed for their managerial efficacy, their perceived mobility, perceived success, and salary.

Managers and direct reports were surveyed in two organizations on a variety of bio-data and personality variables in addition to LSE, number of leadership attempt and organizational commitment.

Administrative staff members at a bank in the UK completed two managerial efficacy measures and were rated by supervisors for their performance.

Australian managers from a large, international automotive company were assessed on a variety of psychological measures which were compared with annual performance appraisals.

Students with prior management experience participated in a multi-stage experiment involving allocating workers to tasks. Participants were either told that decision-making either reflects a stable quality or an acquirable skill.

Employed a three-condition, 38 week longitudinal design with 91 first-year military cadets. Cadets were assessed for leadership efficacy along with a number of leadership styles, performance, and personality variables. Cadets were separated into development, infor mational, and control groups.

Surveyed Australian nursing home directors for perceived control of operations, general managerial efficacy for compliance, and financial means efficacy. Also, longitudinal data were collected assessing government compliance with safety and performance standards.

Male undergraduates were assessed for the desire to be in leadership positions, aspects of leadership efficacy, desirability of leadership qualities, and belief in sources of effective leadership.

\section{Results}

Leader self-efficacy was related to leaders' own ratings of leader-member exchange $(r=.24)$, but not those of followers'. LSE was also correlated with perceptions of follower performance $(r=.30)$. This study indicates possible mechanism by which LSE drives the performance of others.

Managerial efficacy was shown to be significantly related to perceived mobility $(r=.18)$ perceived success $(r=.27)$, and earned salary $(r=.24)$. This study supports the universality of the effects of LSE on leader performance.

Factor analysis showed three factors: direction gain, and overcoming. General LSE was associated with higher manager self-esteem $(r=.42)$ and an internal locus of control $(r=.37)$ in addition to follower abilities $(r=.36)$ and organizational support for change $(r=.26)$. LSE was also associated with higher organizationa commitment $(r=.23)$ and more leadership attempts by managers $(r=.21)$.

Managerial efficacy was significantly related to most performance criteria with the exception of written communication $(r=.14, .21)$ Overall, managerial efficacy was significantly related to supervisor-rated performance $(r=.35, .38)$

Leader self-efficacy was positively related to job performance ratings $(r=.21)$, but did not add incremental predictive validity beyond the effects of political skill, gender, and seniority.

Managerial efficacy was impacted by prior successful performance on tasks. Higher levels of managerial efficacy predicted higher levels of subsequent performance. Individuals induced with an entity schema for ability suffered a loss of managerial efficacy after completing challenging tasks. Individuals told that ability was acquirable sustained their levels of efficacy after encountering challenging tasks.

Overall ALE was stable over time $(r=.78)$ and was correlated with higher levels of self-concept clarity $(r=.33)$, meta-cognitive ability

$(r=.47)$, motivation to lead $(r=.42)$, and senior officer ratings of transformational leadership $(r=.30)$ and performance $(r=.21)$. All sub-domains of ALE showed significant change over the 38 periods in the development group. ALE was also found to predict transformationa leadership, which mediated the relationship between leadership efficacy and performance.

Managerial efficacy was associated with government-rated compliance with laws $(r=.19)$. These effects were significant beyond the effects of perceived control and a variety of control variables. The effects of managerial efficacy were enhanced when the perceived control over the environment was lowest.

Individuals with high levels of leadership aspirations scored higher on effectiveness selfefficacy, ability-match self-efficacy, and ease of success self-efficacy in addition to their positivity towards leadership characteristics and their belief that effective leadership is based on internal sources. 
Table 1. Leader self-efficacy (continued)

\begin{tabular}{|c|c|c|c|}
\hline Subdomains of leadership self- & Target focus & Methods & Results \\
\hline $\begin{array}{l}\text { efficacy } \\
\text { SINGER (1991) }\end{array}$ & $\begin{array}{l}\text { Assessed the role of gender in de- } \\
\text { termining LSE and leadership as- } \\
\text { pirations. }\end{array}$ & $\begin{array}{l}\text { Middle managers were assessed } \\
\text { for leadership efficacy, leader- } \\
\text { ship aspirations, desirability of } \\
\text { leadership qualities, and belief in } \\
\text { sources of effective leadership. }\end{array}$ & $\begin{array}{l}\text { All forms of leadership efficacy tested were } \\
\text { positively correlated with having positive atti- } \\
\text { tudes of leadership characteristics. "Effective- } \\
\text { ness" leadership efficacy was related to lead- } \\
\text { ership aspirations. No aspect of efficacy was } \\
\text { linked with making internal or external attribu- } \\
\text { tions of leadership performance. "Ease of suc- } \\
\text { cess" efficacy predicted leadership aspirations } \\
\text { in women with less than } 2 \text { years of experience. }\end{array}$ \\
\hline
\end{tabular}

investigations focusing on what is called management efficacy (Luthans and Peterson, 2002; Robertson and Sadri, 1993; Wood and Bandura, 1989a). In this review, we will not make the distinction between leader and manager efficacies because for our purposes here we will assume they are representing compatible and similar social roles, e.g., a manager or leader role. Aside from being relatively sparce, most of this body of research is limited in its focus, centering on a leader's confidence in his or her ability to exercise specific behaviors within a narrowly defined task and/or leadership context, such as complying with health and safety issues (e.g., see Jenkins, 1994).

Although leader self-efficacy (LSE) has only become a focus of empirical research very recently, there is growing evidence demonstrating its capacity to predict relevant work outcomes. Examples from Table 1 include ratings of leader potential (Chan \& Drasgow, 2001), attempts to take the lead (McCormick et al., 2002; Paglis and Green, 2002), motivation to lead (Chan \& Drasgow, 2001), organizational commitment (Paglis \& Green, 2002), performance ratings from both peers and superiors (e.g. [Chemers et al., 2000; Luthans and Peterson, 2002; Robertson and Sadri, 1993), as well as organizational performance (Wood \& Bandura, 1989a) above and beyond other predictors.

A number of individual difference factors have also been associated with higher levels of leader self-efficacy. While each of the Big Five (Goldberg, 1993) personality traits has been shown to be significantly related to LSE (Hendricks \& Payne, 2007), elevated conscientiousness and extraversion appear to be the most highly related correlates (Chan and Drasgow, 2001; Hendricks and Payne, 2007). Other personality factors that have been related to LSE include higher levels of self-esteem and internal locus of control (Paglis, 1999). In terms of external antecedents, LSE has been associated with positions that have higher levels of encouragement from current leaders (Mellor et al., 2006), as well as higher levels of job autonomy, resource supply, and organizational support for change (Paglis, 1999).

LSE has not only been associated with higher levels of performance for individual leaders, but it has also been linked to higher levels of performance for groups. One possible mechanism to explain this link is that LSE could serve to increase the collective efficacy of the team (Kane et al., 2002); while increasing the efficacy of the leader as well through the reciprocal effects of more confident and capable team members performing effectively. We can envision a highly efficacious team enhancing the leader efficacy of the individual leader, just as we can see how the leader can build higher levels of collective efficacy.

Perhaps adding to the complexity of linking LSE, individual and team performance, it should be noted that these relationships may also not be entirely linear. For instance, there is evidence that unreasonably high levels of efficacy may be disconnected with the requirements of the situation, and have been shown to actually damage the collective efficacy of teams and their long-term performance (Schruijer and Vansina, 2002; Vargas-Tonsing et al., 2003). In these situations, we might see a naïve level of efficacy on the part of the leader and/or group being led, which may create a downward spiraling effect when the group confronts a challenge they thought capable of addressing, but fail miserably. Thus, just as we theorize leaders' efficacy spiraling up in high-performing groups, we can also envision efficacy spiraling down through what Bandura (1997) terms efficacy calibration errors.

This review of the leader (manager) self-efficacy research thus far leads us to several guiding research propositions for future leadership research to address:

Proposition 1a: Higher levels of leader self-efficacy (LSE) will result in higher levels of leader emergence and performance.

Proposition 1b: LSE will be moderated in its impact on leader emergence and performance by the extent to which the LSE matches the demands of the task and the context in which the leader is embedded.

\subsection{New frontiers of leader efficacy research}

In pursuing new frontiers in research on leader efficacy, we will now draw from basic research in clinical, cognitive, social and educational psychology, as well as organizational behavior. We first take a hierarchical and multivariate approach to examining leader efficacy.

\subsubsection{Toward a hierarchical and multivariate approach to leader efficacy}

In our proposed build-out of the leader efficacy construct, we recognize the need for complex, adaptive leadership (Hannah et al., 2008; Hunt and Phillips, 1991; Marion and Uhl-Bien, 2001],[Marion and Uhl-Bien, 2007; Mumford and 
Connelly, 1991; Mumford et al., 2007; Osborn et al., 2002). Such complex and adaptive leadership requires both leaders and followers to call upon various forms and domains of efficacy to be effective.

Over a decade ago, Gist \& Mitchell (1992) proposed that individuals go through a process of "orchestration" of various antecedents when formulating efficacy beliefs. Applied to leadership, we similarly propose a process of complex interactions between various domains of efficacy (e.g., general and various domain-specific forms of self-efficacy) as leaders contemplate action. Unfortunately, very little research is available that has assessed both general and self forms of leader efficacy in the same study (e.g., [Chan and Drasgow, 2001; Kane et al., 2002). Thus, we propose that a greater multivariate focus is needed which assesses the detailed structure and interactions between the various forms of leader efficacy.

Specifically, we conceptualize leader efficacy using a hierarchical structure in which leaders hold a certain super-ordinate level of generalized efficacy across their various roles and requirements. This is similar to the way that aspects of one's personality are integrated into a leader's general identity across various domain roles (Wood, 2007). However, leaders also maintain subordinate domains of efficacy in terms of their perceived abilities to perform within more narrowly defined combinations of tasks and situations. These more domain-specific efficacies would also be seen as contributing to or detracting from leaders' overall generalized efficacy depending on their prior experiences.

Prior research has shown that specific forms of self-efficacy have discriminate validity from general self-efficacy (Chen et al., 2001). We believe this is because the general self-concept has been conceptualized as being composed of multiple, domain-specific self-concepts associated with emotional, physical and social domains (Marsh and Shavelson, 1985; Shavelson et al., 1976; Wood, 2007). Taking this one step further, leaders' self-concepts are associated with various social roles, such as being a team leader, father, or coach (Hannah and Luthans, 2008; Hannah et al., in press; Woolfolk et al., 2004), in which the individual's level of specific efficacy for a given task may vary from role to role. For example a leader's efficacy for public speaking may vary between his or her team leading and coaching roles.

On the other hand, general efficacy has been conceptualized as a de-contextualized belief where individuals' feel they are capable of meeting general task demands and are able to perform in a broad array of related circumstances and contexts (e.g., [Chen et al., 2001; Eden, 2001). In line with this definition, one might view such generalized efficacy as being more traitoriented versus state-like. Yet, we suggest that the relationship of general to more specific is likely to be more dynamic and interactive than often theorized. We propose that efficacy is neither dichotomously specific nor general, but generalizable and can therefore be portrayed along a continuum. Based on the work of Bandura (1997), we further suggest that over time these subordinate forms of self-efficacy generalize to build the leader's general efficacy in the same way that personality characteristics expressed within specific roles integrate to form general personality characteristics (Wood, 2007).

Building on the arguments above, Bandura (1997) suggests that self-efficacy beliefs are task and context specific, but can be generalized across a range of tasks and situations. He states that "mastery experiences that provide striking testimony to one's capacity to effect personal changes can also produce a transformational restructuring of efficacy beliefs that is manifested across diverse realms of functioning. Such personal triumphs serve as transforming experiences. What generalizes is the belief that one can mobilize whatever effort it takes to succeed in different undertakings" (Bandura, 1997, p. 53). It then logically follows that the more diverse the domain in which leaders build efficacy beliefs, the more likely they will be able to activate their efficacy, and will be more adaptable and effective within and across these domains. Bandura (1999) notes that a wide generalization of efficacy beliefs across contexts can resemble a personality disposition, but importantly still does not have the de-contextualized nature proposed in most conceptualizations of general efficacy and other more global constructs such as self-esteem.

The process of generalizing efficacy beliefs as proposed by Bandura has to date received very little attention. Initial evidence provided by Kane et al. (2002) suggests that when leader self-efficacy is more narrowly defined (in this case as leader efficacy for the specific task of increasing an organization's market share), one's more generalized self-efficacy beliefs may influence the formation of task-related or specific self-efficacy beliefs. We suggest that a more refined definition of what constitutes the domain to which leaders generalize their efficacy may be a critical point of departure for advancing our understanding of leader efficacy development and leader performance discussed in more detail below. Further, such refinement may inform current issues of discriminate validity between general efficacy and other global constructs such as selfesteem, locus of control, and core self-evaluation traits (see [Chen et al., 2001; Judge et al., 1997; Judge et al., 2003).

In sum, we suggest that a leader with a wide domain of self-efficacy will by definition perceive himself or herself as more adaptable to meet a diverse array of leadership challenges (Hannah et al., in press). Consequently, we suggest greater understanding is needed regarding how leaders' efficacy beliefs for specific tasks interact within their broader self-concept and with their general efficacy beliefs to provide greater overall levels of efficacy - and thus adaptability and performance-across numerous challenges, roles and performance contexts. At this point it is not clear, nor has it been empirically determined whether generalized efficacy drives more specific forms of efficacy, or the more specific forms of efficacy drives the more general; or whether the effects are reciprocal in reinforcing each other. For example, an individual may believe that he or she is generally a good communicator with others, and thereby determine he or she is more capable of communicating as a leader. Whereas, someone who has had a broad range of leadership communications experiences may come to view his or her overall communication capabilities as being strong. This leads to our second proposition:

Proposition 2a: Specific forms of leader efficacy and generalized leader efficacy will reinforce one another and interact in building overall leader efficacy.

Proposition 2b: Leaders with a greater breadth of generalization of their LSE will be more adaptable across contexts and situations. 


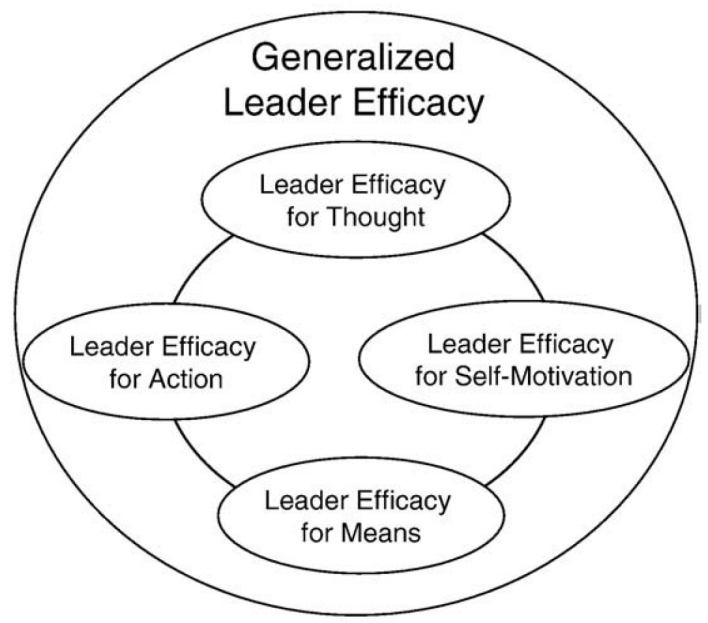

Figure 2. Hierarchical and multivariate structuring of leader efficacy.

\subsubsection{Examining domain-specific leader efficacy}

Beyond the refinements needed between general and self-efficacy, we suggest that future leadership research also needs to investigate specific types of LSE. The overwhelming majority of empirical studies in our review that tested leader self-efficacy limited their focus to leaders' efficacy for specific behaviors. In building a more robust conceptualization of leader efficacy, we suggest that dynamic leadership challenges require leaders to have not only confidence in their abilities to take action (Parry, 1998), but also in their abilities to regulate their thoughts and self-motivation processes (Bandura, 1989; Wood and Bandura, 1989b). The same holds for efficacy in the means they have at their disposal in their environment (Eden, 2001). These various forms of efficacy have yet to be tested in combination in any prior leadership research.

We propose that LSE is also embedded in the broader social cognitive framework that enables human agency (Bandura, 2001). To establish agency and ownership over their area of responsibility and to fully engage themselves, leaders must be efficacious in a number of ways. For example, they must believe they can generate leadership solutions, motivate themselves to engage in leadership challenges, enact appropriate behaviors, and find support in the various means in their environment to ensure success. We believe that the exclusive focus of previous research on the action/behavioral forms of efficacy has been insufficient and likely will not only fail to explain how LSE is developed, but also how it manifests in the complex dynamics of the leader, follower and context. We take the position that these other dimensions are interdependent and that if any dimension is insufficient, the leader may fail to act or at least not fully engage. When all dimensions are sufficient, however, leaders should be more engaged and effective, as would be also expected of their followers.

We now draw from the existing multidisciplinary body of work for each of the critical domains of leader efficacy to examine more closely several key components described above including thought, self-motivation, means, and action leader efficacy. Specifically, drawing from the multivariate and hierarchical structuring of efficacy beliefs presented earlier, we present in Figure 2 a broader and more integrated framework for examining multiple domains of LSE. We believe that accounting for the components of LSE will allow us to explain greater variance in leader emergence and performance.

\subsubsection{Leader thought efficacy}

It is widely recognized that leadership is viewed as requiring complex cognitive/social problem solving skills (Yukl, 2002). Therefore, heightened cognitive capacity, complexity and abilities have been a central feature in many models of leadership capability (e.g., [Conway, 2000; Dennison et al., 1995; Hannah et al., in press; Hooijberg et al., 1997; Hunt and Phillips, 1991; Mumford and Connelly, 1991; Mumford et al., 2007; Quinn, 1988).

In the 2007 LQ yearly review, Mumford et al. (2007) provided a framework to explain what constituted leader cognition in dynamic contexts. While their model offers a rich understanding of leader cognition, it does not address the impact individual differences have on such cognitions and thus leaders' thought repertoires. Yet, we know that self-efficacy influences both the extent and manner leaders' employ cognitive abilities (Wood \& Bandura, 1989a) as well as general memory functioning (Hultsch, Hertzog, Dixon, \& Davidson, 1988), cognitive performance (Schunk \& Gunn, 1986), and both attention and cognitive processing resources (Berry, 1987; Berry, 1989).

We suggest that efficacy for thought is central to a leader's ability to generate effective solutions for leadership challenges and dilemmas. Bandura (1989) outlines the critical role of efficacy beliefs in the regulation of cognitive processes, stating that, "people's perceptions of their efficacy influence the types of anticipatory scenarios that they construct and reiterate. Those that have a high sense of efficacy visualize success scenarios that provide positive guides for performance and they cognitively rehearse good solutions to potential problems"' (p. 729). Such positive 'success visualization' and rehearsal is enabled by the agentic capability of human forethought and has been shown to further enhance subsequent performance (Bandura, 1989; Carroll and Bandura, 1987; Kazdin, 1978). Supporting this claim, (Wood and Bandura, 1989a) and (Wood and Bandura, 1989b)) found that self-efficacy beliefs for managerial decision-making, mediated by goal-setting, positively 
affected the manager's use of effective analytic strategies, resulting in increased organizational performance. This is consistent with Schmidt \& Ford's (2003) findings that meta-cognitive processing was a strong predictor of heightened self-efficacy, goal orientation, mastery orientation, and superior training performance. Those with higher levels of mastery orientation have in turn been shown to allocate greater effort to scrutinize their learning and to seek more performance feedback (Butler, 1993; VandeWalle et al., 2001). All of these factors have been shown to increase self-efficacy (Bandura, 1997).

Another critical sub-component of our conceptualization of thought efficacy is learning efficacy (Bandura, 1997). Applicable to examining and understanding how the acceleration of leader development occurs, Kanfer \& Ackerman (1989) demonstrated that learning efficacy is a predictor of a person's ability to acquire complex skills. Consequently, to the extent we can build greater capacity for learning efficacy, we may be able to have a direct and positive impact on both the leader's knowledge, skills and abilities and the efficacy beliefs associated with the application of those KSAs (Lord \& Hall, 2005). Such learning efficacy may ultimately affect the potential to lead within and between particular domains and to impact leader development, emergence and effectiveness. This leads to our third set of research propositions:

Proposition 3a: A leader's level of thought efficacy will be related to the leader's ability to learn and formulate leadership solutions.

Proposition 3b: Higher levels of leader thought efficacy are expected to result in higher levels of leader development, emergence and performance.

\subsubsection{Leader efficacy for self-motivation}

We next propose that investigation of efficacy for personal self-motivation may be central to advancing our understanding of what constitutes leader engagement and performance. Extensive research outside the leadership field has documented the role of efficacy in the regulation of one's motivation (see [Bandura, 1997; Stajkovic and Luthans, 1998). The ability of a leader to self-motivate is a central tenet in theories of leadership identity processes (e.g., Lord \& Brown, 2004), transformational leadership, (Avolio, 2002; Bass, 1985), motivation-to-lead (Chan \& Drasgow, 2001), self-leadership (Manz, 1986), and managerial role-motivation (Miner, 1993).

Bandura (1989) states that cognitively generated motivation, which Kanfer (1987, p. 260) terms "intentions for effort allocations", is a product of the exercise of forethought that allows envisioned successful future outcomes to become a source of motivation to regulate current behaviors. It has been suggested that through this transforming process, the motivational component of self-efficacy contributes to goal-setting separately and independently from one's abilities (Kane et al., 2002; Phillips and Gully, 1997). Additionally, Singer (1991) found that efficacy beliefs partially accounted for motivation for leadership aspirations for both men and women, particularly if they had more experience. This leads to our next research proposition:

Proposition 4: Leaders' level of efficacy for self-motivation will be related to the level of effort they allocate to both thinking through and performing in challenging circumstances.

\subsubsection{Leader efficacy for means}

The final domain of leader efficacy that we suggest is critical, but has not yet received attention in leadership research, is means efficacy (Eden, 2001). Since human functioning is socially situated, as shown in Figure 2, the means and/or resources available to human agents to perform tasks must be considered when examining an individual or group's perceived capability and subsequent motivation to perform. Means efficacy therefore results from perceptions of an enabling and supportive context. Given the importance of context to leadership (Osborn et al., 2002), we were surprised when our search uncovered only a few empirical studies that had directly investigated the means efficacy of leaders.

Highlighting the influence of an enabling environment in fostering engaged leadership, Wood \& Bandura (1989a) found that when managers were exposed to an organizational context they believed they could control, they displayed higher levels of efficacy and set increasingly more challenging goals. Conversely, when managers were exposed to contexts they felt they could not control, they quickly lost self-efficacy and performance deteriorated, even when goals were in easy reach. However, it should be noted that while leaders higher on LSE typically view situations as more controllable, they are also less likely to perceive crises in their work environments (Paglis \& Green, 2002).

(Eden, 1996) and (Eden, 2001) suggests that one's subjective efficacy involves an assessment of all of the available resources that can be used to perform one's tasks. One's internal resources include perceptions of such things as knowledge, experience, skills, and endurance, which we have referred to above as constituting self-efficacy. Beyond these internal resources, however, Eden (2001) also indicates that there is a subjective external efficacy he labeled means efficacy. Eden (2001) states that these resources can include implements (e.g., equipment and computers), other persons (e.g., coworkers, followers, and supervisors), or bureaucratic means for accomplishing work (e.g., procedures and processes). We will hold off addressing the influence of other people as a resource (i.e., collective efficacy) in detail until we take up the topic of collective efficacy.

To date, there are just a few related studies actually examining the linkages between self and means efficacy. For example, in a recent study of banking employees, the effects of transformational leadership were found to be partially mediated by the interaction of self-efficacy and means efficacy (Walumbwa, Avolio, \& Zhu, in press). LSE has also been positively related to perceptions of resource supply as well as the presence of organizational support (Paglis, 1999). The influence of means efficacy may be domain-specific. Eden (2001) stipulates that tasks differ to the extent they are means dependent. In jobs that involve heavy use of external means, there is beginning evidence that means efficacy may even 
overshadow self-efficacy in determining performance (Eden, 2001; Eden and Sulimani, 2002). These jobs might include complex tasks where sophisticated technology is required to perform effectively, e.g., in nuclear facilities, and in some cases these means may even substitute for leadership.

Again, based on the discussion above, we can see how the context and LSE interact to impact overall levels of leader and follower efficacies. This dynamic may be particularly important as we move towards examining leadership in more extreme or life threatening contexts. In these situations, we contend that the confidence the leaders hold in themselves and create in followers, as well as the salience of means will likely be magnified given the costs of failure. This leads to our next set of propositions:

Proposition 5a: Leaders' assessment of the utility of various means available for task performance will influence the determination of their overall efficacy beliefs in a given domain.

Proposition 5b: LSE will be mediated by the leader's means efficacy in terms of LSE's relationship with performance.

\subsection{Generalizability of efficacy and leader adaptability}

Researchers have attempted to define what constitutes effective and adaptive leadership for complex situations (Dennison et al., 1995; Hooijberg et al., 1997; Marion and Uhl-Bien, 2001; Marion and Uhl-Bien, 2007). We believe that the multivariate approach to leader efficacy shown in Figure 2 can advance our understanding of what constitutes such leader adaptability. Specifically, we suggest that a robust span (i.e., generalization) of efficacy beliefs will enable leaders to execute a wider range of leadership behaviors in order to adapt to and match dynamic situational demands (Lyons \& Murphy, 1994). This view is consistent with Fredrickson's (Fredrickson, 2001; Fredrickson et al., 2003) findings that efficacy and other positive states build "personal resources" to counteract the narrowing of thought-action repertoires that are otherwise induced under stress. An example would be situations faced during challenging leadership dilemmas or in what we have referred to above as extreme contexts such as in military combat. We suggest that personal resources such as a leader's efficacy allow leaders to broaden their potential repertoires through greater thought efficacy and their ability to visualize a greater span of success outcomes (Kazdin, 1978; Wood and Bandura, 1989a). This would seem to be especially true in situations where stress levels may be exceedingly high and which serve to constrain a leader's thoughts and behaviors.

\subsubsection{Efficacy and adaptable leadership styles}

Conceptualizing how a broader domain of generalized efficacy promotes adaptable performance can be exemplified by using what has been called the full range leadership model (Avolio, 2002; Bass and Avolio, 1997). This model predicts that effective leaders are able to alter their leadership styles from more or less transactional or transformational in order to address dynamic situational demands. In situations that are more stable and clear cut, transactional leadership may suffice for effective performance (Bass, 1985). On the other hand, in situations where new rules are being created and the situational determinants are unpredictable, a more transformational leadership approach may seem warranted (Avolio, 2005).

We hold that some leaders will perceive themselves as efficacious to perform across the broad spectrum of both transactional and transformational leadership as called for by the situation, which is advocated by the full range model. By the same token, other leaders may be more limited in their efficacy, limiting their repertoire to either the higher or lower end of that spectrum. In connecting leader efficacy research to the full range model, we are suggesting that a leader's efficacy to choose these styles will likely vary, therefore impacting the leader's ability to be adaptive as the situation changes over time.

One promising example for potential future research would be if a multi-factor leader efficacy measure was developed representing the various domains of leader efficacy we have outlined above. A measure representing a span of leader behaviors, e.g., the Multifactor Leadership Questionnaire (Bass \& Avolio, 1997) could then be used as a criterion to test the generalizability of LSE as we have conceptualized. Here we would expect that higher scores across a broader set of efficacy factors would predict higher scores across a broader range of the full range factors and situational challenges.

More specifically, since self-efficacy beliefs are self-concept based (Bandura, 1997), research findings linking leaders' self-concepts to their behaviors across this full range is important to the advancement of leader efficacy. Specifically, Wooford and colleagues found that leaders develop a mental structure that could be characterized as either more transactional or more transformational, that in turn respectively predicted transactional and transformational behaviors (Wooford and Goodwin, 1994; Wooford et al., 1998). Therefore, we suggest that future research should investigate how leaders create and employ differential efficacy beliefs in transactional and transformational leadership abilities of thought, self-motivation, action, and means.

In sum, we suggest that it would be worthwhile to link the different domains and levels of efficacy to predict leaders' use of specific leadership styles and orientations. We used as an example the full range leadership model, but we expect that such linkages could also be made with other models, e.g., leader-member exchange (Graen \& Uhl-Bien, 1995) or path-goal theory (House, 1996). In these instances, we could see how a leader's efficacy for self-motivation might impact how motivated the leader is to build high quality relationships with followers, or how his or her thought efficacy promotes him or her to think through the best means and paths for followers to achieve objectives. In these instances, we could see how thought efficacy could impact both the effectiveness of the leader-member exchange and how motivated a follower is to pursue a particular goal. This leads to the following research question:

Research Question 1: How might integrating leadership orientations and styles with the various levels and domains of efficacy help further clarify how and in what ways leaders employ various leadership styles across situations, and in turn impact motivation and performance? 


\subsection{Examining the leader's self-system and efficacy}

So far we have proposed opportunities to advance leader efficacy research through investigating the hierarchical structuring and multiple domains of efficacy. Now we propose that a parallel and more inclusive focus is required as to how these various types of efficacy beliefs operate within the individual's self-system. As noted, prior research has predominately measured isolated domains of leader efficacy (e.g., self-efficacy) through self-survey methods as if that domain is a quality that can be assessed in isolation. We heed the observation by Dweck, Higgins, \& Grant-Pillow (2003, p. 239) that, "self variables, such as expectancies, self-efficacy, self-attributions, and self-esteem, cannot be properly studied or understood outside of the context of self-systems." The reason for this noteworthy caution is that all these constructs are linked to dynamic self-regulatory systems which are based in self-concepts (Carver and Scheier, 1998; Cropanzano et al., 1993; DeShon and Gillespie, 2005; Lord and Brown, 2004). We therefore propose that to better understand leader behavior within and across contexts, future research needs to conceptualize leader efficacy as part of a dynamic self-system as we now explain in more detail.

\subsubsection{LSE orchestration and the self-system}

As indicated earlier, the work of Gist \& Mitchell (1992) suggested that an orchestration process may be operating whereby various forms of efficacy (i.e., means, self, general) are interdependent and serve to establish leaders' overall level of efficacy in a given task. Some initial attempts have been made to assess efficacy using such a multivariate framework. For example, the higher-order construct referred to as psychological capital (Luthans et al., 2007; Luthans et al., 2007) combines efficacy with hope, optimism, and resiliency; while core self-evaluation traits (Judge et al., 1997; Judge et al., 2003) combine generalized self-efficacy with self-esteem, locus of control, and emotional stability. The predictive validity of the core constructs over that of the sum of their individual parts suggests that some form of interaction within the self as individuals summon various resources to affect their thoughts, motivation and behavior. To analogously assess the dynamic process of leader efficacy, we suggest that future research might assess the interactions of various forms of efficacy within the self-system in which they operate. To explicate such an orchestration process, we draw from Hannah, et al.'s (in press) model of positive leader self-structure as an example of a guiding framework for such future research.

The self is an elaborate and multi-dimensional structure that is differentiated as individuals classify various attributes based on their application to certain social roles and not others (Kihlstrom et al., 1994; Markus and Wurf, 1987). For instance, a leader may have self-efficacy for verbal communications in his or her role as a "product manager", but not in his or her role as a "spokesperson." Further, this leader may hold differing levels of efficacy for the means available for each of these roles that could promote or deter their engagement when assessed in conjunction with their self-efficacy. Therefore, Hannah et al. (in press) argue that when assessing positive forms of leadership it may be important to assess both content (types and levels of efficacy) as well as structure (patterns of inclusion of efficacy across roles).

Drawing from the work on self-complexity (Linville, 1987; Woolfolk et al., 2004), Hannah et al. (in press) suggest that the greater the amount of positive content a leader holds in his or her self-concept-and the more that content is interlinked with other positive contents across a greater span of roles - the more likely he or she will be to access a set of positive attributes (e.g., efficacy) relevant to any given leadership role. This process occurs as relevant positive aspects of the self are "triggered" or primed and the leader in turn automatically activates other linked self-aspects that are pertinent to the context (Hannah and Luthans, 2008; Higgins et al., 1998). Through this series of priming, a leader's cognitions, expectancies, affects, goals, values, and self-regulatory plans become activated (Johnson et al., 2006; Mischel and Shoda, 1998; Shoda et al., 2002). We suggest that this activated portion of the self can be viewed as a more or less "efficacious working self-concept" that promotes a leader to engage in some roles and not others (Lord \& Brown, 2004).

In sum, we recommend that future research assess the extent to which a leader possesses multiple types of efficacy (forms of self, means, collective and general) within and across a broad range of social roles and situational contexts and challenges. Research then might investigate how leaders engage and perform across those specific roles and contexts for which they have greater and lesser levels of the various forms of efficacy, thus taking into consideration the critical role that the structure of efficacy beliefs play in the self-system. Such a refined approach might well inform leader development for specific contexts, which leads to our next research question.

Research Question 2: In what way does the content and structuring of leaders' efficacy beliefs, as represented across the social roles contained in their self-concepts, influence their engagement and performance across leadership roles and levels of difficulty of tasks within those roles?

\subsubsection{Automaticity of leader efficacy}

Closing out our discussion of the critical role of leader efficacy in influencing leader behavior, research has shown that when people believe that they have the attributes required to meet challenges that they will, as reinforced over time, develop a standardized response pattern. This happens when they are faced with similar demands in the future, allowing self-regulation to be controlled by lower level sensorimotor systems (Carroll and Bandura, 1987; Gioia and Poole, 1984). With high levels of practice and familiarity, even complex events can become less demanding or even automatic processes for experienced individuals (e.g., [Logan and Klapp, 1991; Spelke et al., 1976; Zbrodoff and Logan, 1986).

Future research might investigate if an efficacious and complex leader self-concept is developed and reinforced over time through successful performance, whether "efficacious scripts" might be developed in leaders that relate to particular events or episodes for which they apply. Scripts are a form of event-driven schema (Abelson, 1981; Gioia and Poole, 1984; 
Schank and Abelson, 1977). We propose that these scripts can be predictive of efficacy-related behavior, such as was found in promoting transformational leadership (Wooford \& Goodwin, 1994). This area of research might better explain how certain leaders seem to emerge and be attributed as being a 'natural' leader, when in fact their emergence may be largely due to a habituated sequence of efficacious script responses. Building on the discussion above is our sixth proposition:

Proposition 6: Leaders with more complex, efficacious self-concepts will develop a broader set of efficacious scripts that are primed for automatic use across wider domains of leadership situations.

\section{A Multi-level approach to leadership efficacy}

Having advanced a robust conceptualization of leader efficacy as being comprised of general, means, and various domains of self-efficacy, in this section we link the leader's efficacy as shown in the upper left portion of Figure 1, through his or her behaviors (leading), to build follower and collective efficacies. Our purpose here is to advance a theory of leadership efficacy as a dynamic, multi-level construct. This is a logical extension as leadership is by definition a collective multi-level process, especially toward more strategic levels in organizations (Klein et al., 1994; Rousseau, 1985; Yammarino et al., 2005). Specifically, we focus on examining how leadership efficacy may be best conceptualized as an emergent and collective process. Based on our intent to build an expanded multi-level perspective of leadership efficacy, Table 2 contains summaries of articles that guided our thinking where leader behaviors were investigated in relationship to follower self-efficacy, as well as group or collective efficacy.

\subsection{Leader and follower bidirectional influence}

Previous research has clearly shown that leaders can affect the self-concept of followers through role modeling (e.g., [Gardner and Avolio, 1998; Lord and Brown, 2004). In line with an information-processing approach, followers tend to develop a schema of prototypical leadership qualities based on attractive leaders (Ibarra, 1999; Lord et al., 1984). This suggests that the leader's efficacious behaviors may become prototypical in the form of idealized behaviors that members of the organization would come to identify with over time and be influenced by in terms of their own self-concepts of efficacy (Hogg, 2001; Shamir et al., 1993). Thus, higher levels of leader self-efficacy could be expected to contribute to positive leader-follower relations and performance over time (Murphy and Ensher, 1999; Taggar and Seijts, 2003), which could in turn reinforce the leader's self-efficacy.

Besides modeling, we also note that persuasion and emotional arousal are important sources of efficacy development. This is important to building leadership efficacy as we know that leaders can have emotional contagion effects where leaders communicate positive emotions to followers (Bono and Ilies, 2006; Naidoo and Lord, 2008) further increasing the attractiveness of the leader. We suggest that this process can become bidirectional, and self-sustaining because followers also have influence on the affect and self-concepts of leaders (Shamir et al., 1993). Further, as seen in Table 2, a number of researchers have found links between leadership behaviors and the efficacy levels of their followers (Dvir et al., 2002; Kark et al., 2003; Kirkpatrick and Locke, 1996; Pillai and Williams, 2004).

As suggested in Figure 1, as leaders and followers interact in dyads, we suggest that they reciprocally influence each other's sense of efficacy. Supporting this position, Howell \& Shamir (2005) argue for a much more active interpretation of what constitutes the follower in the leader-follower dynamic. Kark \& Shamir (2002) explored this dynamic indicating that followers with a more stable self-identity, and we would add efficacy, may affect leader-follower interaction dynamics in ways perhaps unintended by the leader. Specifically, a follower's efficacy at critical times may reinforce the leader to continue forward, which in turn may bolster the follower's efficacy, resulting in a pattern with each collectively 'spiraling up' the efficacy of the other. Indeed, the display of efficacious behaviors by followers and demonstration of their skills to face a given task would not only serve a role modeling function and source of social persuasion for the leader (Bandura, 1997), but can also serve to raise the collective efficacy of the group (Bandura, 2000) and the follower's own efficacy (Phillips, 2000). Importantly, preliminary research has in fact shown that LSE is associated with encouragement and persuasion from others (Mellor et al., 2006).

The degree to which the follower's efficacy might impact the leader may depend on the type of leader in a particular situation. For example, Howell \& Shamir (2005) described certain leaders as having a more relational identity orientation, who we would expect to be more likely to seek direction, self-validation, and satisfaction from their personal relationships with valued followers. Following this logic, we could expect that leaders in high quality relationships with followers would be more likely to be influenced by those followers in how they think and behave. For those followers in such relationships that display higher levels of efficaciousness, we would expect them to lend more confidence in the leader to take action. This discussion leads to our next proposition:

Proposition 7: Through their display of efficacious behaviors, followers and leaders will reinforce the efficacy of each other over time.

\subsection{Collective efficacy}

As portrayed in Figure 1, we believe that efficacious behaviors by both leaders and followers interacting with the group will build collective efficacy. Collective efficacy has been defined as a group's shared belief in its conjoint capabilities to organize and execute the courses of action required to produce specific levels of accomplishments (Bandura, 1997; Prussia and Kinicki, 1996). Collective efficacy however does not equate to leadership efficacy. Leadership efficacy is a special 
Table 2. Leadership, leadership self-efficacy, and collective efficacy

$\begin{array}{lll}\begin{array}{l}\text { Leadership efficacy and collec- } \\ \text { tive efficacy }\end{array} & \begin{array}{l}\text { Target focus } \\ \text { To study the antecedents and out- }\end{array} & \begin{array}{l}\text { Methods } \\ \text { Experimental groups of students } \\ \text { KANE ET AL. (2002) }\end{array} \\ & \text { comes of general and task-specific } & \text { completed a production task. }\end{array}$

Leadership and collective efficacy

ARNOLD ET AL. (2001)

Investigated the effects of transfor-

HoYT \& BLAsCOVICH (2003)

Assessed the impact of leadership style in both virtual and face-tomational leadership on collective efficacy, trust, and commitment. face settings.

Work groups of MBA students completed questionnaires regardefficacy, team displays of leadership behavior, and attitudes.

Leadership style and group-setting were manipulated in an experimental setting. Team member were assessed for creativity, selfand collective efficacy, trust, satisfaction, and value congruence.

A model of leadership efficacy, collective efficacy, and group performance was tested. participated in a hiring task as
WATSON (2003)

Jung \& SOSIK (2003)

KaHAi et al. (2003)

Ross \& GRAY (2006)

WALUMBWA ET AL. (2004)

Watson, Chemers, \& Preiser (2001)
Examined whether transformational leadership was positively related to followers' perceptions of empowerment, cohesiveness, and effectiveness.

Examined the effects of leadership style, anonymity, and rewards on creativity-relevant group processes.

Examined the relationship between transformational leadership, collective efficacy, and commitment to organizational values in educational settings.

Investigated the roles of transformational leadership and collective efficacy on job attitudes.

Studied the antecedents and consequences of collective efficacy in competitive groups. ing their perceptions of collective

\section{Results}

General LSE was not related to collective efficacy $(r=.05)$. Task-specific LSE was positively correlated with collective efficacy $(r=.26)$. Both LSE and collective efficacy were predictive of group profitability.

Higher levels of transformational leadership were associated with collective efficacy $(r=.64)$, trust $(r=.72)$, and commitment $(r=.60)$. Perceptions of an "iron cage" were unrelated to collective efficacy beyond the effects of transformational leadership.

Transformational leadership was associated with decreases in quantitative performance, but increases in qualitative performance. Collective efficacy was unrelated to leadership style ( $\mathrm{rs}=.00-.19$ ) and did not play a role in mediating the leadership-performance relationship. Collective efficacy was significantly related to satisfaction with the leader $(r=.33)$ and group cohesiveness $(r=.43)$.

In two laboratory studies, students LSE was positively correlated with task effimembers were as- ficacy by the leader $(r=.22)$, but was unrelatsessed for LSE, perception of col- ed to follower estimates of collective efficalective efficacy, and task efficacy $\quad \mathrm{cy}(r=.04)$ and group performance $(r=.02)$. in addition to group performance. Structural equation modeling revealed that LSE predicted collective efficacy judgments of leaders, which in turn predicted follower collective efficacy judgments. Follower collective efficacy judgments were positively related to group performance $(r=.36)$.

Employees in several large Korean firms completed the surveys regarding their perceptions of leadership, empowerment, group cohesiveness, collective efficacy, and team performance.

Experimental groups were run using simulated leadership styles. Groups were tasked with making decisions about ethical dilemmas. Anonymity of contribution and reward-distribution were manipulated.

Surveyed elementary school teachers in several Canadian school districts for perception of their principal's transformational leadership, their collective efficacy as teachers, and their commitment to organizational values.

Administered surveys measuring perceptions of leadership behaviors, collective efficacy, and job at titudes to financial services employees in China and India.

Transformational leadership was predictive of both feeling of empowerment and group cohesiveness. Feelings of empowerment mediated the effects of transformational leadership on collective efficacy. Both collective efficacy and transformational leadership were predictive of perceptions of team performance.

Transactional leadership was associated with greater group efficacy and creativity than transformational leadership. Higher group efficacy was also associated with both higher satisfaction for the task ( $r \mathrm{~s}=.67-.69)$ and satisfaction with the leader $(r \mathrm{~s}=.31-.42)$.

Perceived transformational leadership correlated significantly with teacher collective efficacy $(r=.45)$. Further, this relationship mediated the relationship between transformational leadership and follower commitment to organizational values.

Transformational leadership was associated with higher levels of collective efficacy $(r=.28)$. Collective efficacy mediated the relationship between transformational leadership and job attitudes.

Surveyed the leader, self, and collective efficacy in NCAA basketball teams along with objective and subjective assessments of performance.
Leadership efficacy and the average efficacy of the team were correlated with collective efficacy. Individual self-efficacy was significantly related to objective individual performance lated to objective group performance. while collective efficacy was significantly re- 
Table 2. Leadership, leadership self-efficacy, and collective efficacy (continued)

\begin{tabular}{lll}
\hline Leadership and means efficacy & Target focus & Methods \\
WALUMBWA ET AL. (2008) & $\begin{array}{l}\text { Examined the effects of transfor- } \\
\text { mational leadership on identifica- } \\
\text { tion and efficacy. }\end{array}$ & $\begin{array}{l}\text { Us bankers were surveyed via } \\
\text { surveyed for their perceptions of } \\
\text { their leader's transformational }\end{array}$ \\
& $\begin{array}{l}\text { leadership. Several months later, } \\
\text { employees rated their means and }\end{array}$ \\
& $\begin{array}{l}\text { self-efficacies in addition to their } \\
\text { identification with the work unit. }\end{array}$ \\
& $\begin{array}{l}\text { Leaders provided performance rat- } \\
\text { ings of employees. }\end{array}$
\end{tabular}

DVIR ET AL. (2002) Tested the impact of transformational leadership on follower development and performance.

Infantry cadets in the Israeli Defense Forces were put through experimental and control workshops to enhance their leadership skills and follower efficacy. Performance assessments were made in subsequent assigned roles.

\section{EDEN (1992)}

KiRKPATRICK \& LOCKE (1996) Tested the effects of different aspects of charismatic leadership on the efficacy and performance of followers.

Tested whether or not the self-efficacy of followers was heightened when the expectations of leaders were raised.

In a randomized experimental design, some instructors in the Israeli Defense Forces were informed that some of their trainees had superior potential. Trainees were assessed multiple times for their self-expectations of performance.

In an experimental study using business students, three core aspects of charismatic leaders were manipulated using actors. a moderator of the relationship

Pillai \& Williams (2004)

SHAMIR, ZAKAy BREININ, \& POPPER (1996)

SHEA \& Howell (1999)
Tested whether transformational leaders create high-performing work groups by enhancing follower efficacy and cohesiveness. of leadership behaviors on a variety of follower outcomes.
Tested the effects of various types
Examined team performance as between decision influence and group outcomes.

Student participants took part in a military decision-making simulation in groups. Groups were assessed for performance level and leader utilization of staff member input. Staff members were assessed for follower efficacy, satisfaction with their leader, task withdrawal, and willingness to return.

Fire rescue employees completed a questionnaire assessing the transformational leadership of their leaders, their group cohesiveness, perceptions of the group's performance, and their own follower efficacy and organizational commitment. li Defense Forces, leaders were assessed for whether they were supportive, ideological, exemplary, or emphasized collective identity.

Followers rated their efficacy and a number of attitudes about the leader and unit.

Tested the effects of leadership style and feedback on efficacy and performance.

Graduate students participated in a work task either under a charismatic or non-charismatic leader.
Using a sample from the Israe-

\section{Results}

Transformational leadership was positively related to means efficacy $(r=.25)$. Means efficacy of followers was positively related to supervisor-rated performance $(r=.24)$ and moderated the effects of both identification and self-efficacy on performance.

Followers who received transformational training increased in their own efficacy more than those who took part in the non-transformational training. The followers of those who were trained in the transformational condition performed at higher levels than the followers of those in the control condition.

Both the efficacy and performance were significantly higher for those trainees with instructors who expected them to perform at higher levels.

Leader vision impacted follower self-efficacy for quality $(r=.18)$ which, in turn, was related to follower performance for quality $(r=.51)$. Task cues from the leader were also related to follower efficacy for quantity $(r=.15)$ which was significantly related to follower performance for quantity $(r=.57)$.

The amount of influence accorded to staff members was associated with follower efficacy in high-performing groups $(r=.17)$ but not in low performing groups $(r=.03)$. Higher levels of follower efficacy were associated with higher group performance $(r=.18)$, higher willingness to return $(r=.19)$, and lower task withdrawal $(r=-.27)$.

Transformational leadership was positively related to both cohesiveness $(r=.42)$ and follower efficacy $(r=.14)$. Both cohesiveness and efficacy partially mediated the relationship of transformational leadership with performance and organizational commitment.

Leaders with an ideological emphasis had followers with lower levels of efficacy $(r=-.09)$. Other leader behaviors were unrelated with follower efficacy levels. Participants rated their own efficacy for the task at multiple times.
Follower efficacy was significantly related to quality performance across trials $(r \mathrm{~s}=.33-$ .52). Follower efficacy mediated the effects of a feedback-leadership interaction on performance. 
Table 2. Leadership, leadership self-efficacy, and collective efficacy (continued)

\begin{tabular}{|c|c|c|c|}
\hline Leadership and follower efficacy & Target focus & Methods & Results \\
\hline $\begin{array}{l}\text { Leadership, collective efficacy, } \\
\text { and follower efficacy }\end{array}$ & $\begin{array}{l}\text { Tested whether leader behaviors me- } \\
\text { diate the relationship between role } \\
\text { (leader and staff) efficacy and collec- } \\
\text { tive efficacy. And whether collective } \\
\text { efficacy mediated relationship be- } \\
\text { tween leader behaviors and perfor- } \\
\text { mance. }\end{array}$ & $\begin{array}{l}\text { Business undergraduates formed } \\
\text { small groups in a laboratory setting } \\
\text { and were instructed to design and } \\
\text { build a prototype of a bridge under } \\
\text { time constraints. }\end{array}$ & $\begin{array}{l}\text { LSE was significantly correlated with both } \\
\text { leader behaviors }(r=.35) \text { and collective ef- } \\
\text { ficacy }(r=.29) \text {. Leader behaviors were sig- } \\
\text { nificantly correlated with collective effica- } \\
\text { cy }(r=.43) \text {, but only collective efficacy was } \\
\text { significantly related to team performance } \\
\text { outcomes }(r=.48) \text {. Results supported the } \\
\text { proposed double-mediation model. Fur- } \\
\text { ther, that leader and follower efficacies in- } \\
\text { teract to predict collective efficacy. }\end{array}$ \\
\hline
\end{tabular}
follower efficacy

CHEN \& BLIESE (2001)

Tested the antecedents of efficacy beliefs across levels of analysis.
Surveys assessing follower and col- The collective efficacy of units was unrelective efficacies in addition to rat- lated to average experience, psychological ings of organizational climate and strain, and role clarity. Collective efficacy work experience were administered was positively associated with perceptions to military personnel.

of a positive leadership climate among upper-level officers. Leadership climate at a higher level related to follower efficacy through role clarity while leadership climate at a lower level related to follower efficacy through psychological strain.

KARK, SHAMIR, \& CHEN (2003) Tested whether followers identify Israeli bank managers were rated by Transformational leadership was positivemore deeply with transformational followers for their transformation- ly related to follower efficacy $(r=.13)$ and leaders and whether identification al leadership. Followers rated them- collective efficacy $(r=.31)$. This relationleads to greater follower efficacy. $\quad$ selves for their own follower effica- ship was mediated by social identification cy, identification with the leader, and with the leader. their collective efficacy.

case of collective efficacy related to the domain of leadership, and thus those positive collective influence processes promote a group's beliefs that they can engage and perform. Although collective efficacy is commonly thought of as being built through group interaction, Bandura (2000) notes that collective efficacy beliefs themselves operate within the individual through similar processes as self-efficacy. Specifically, collective efficacy is gained through successful group interaction, yet stored in the minds of the individuals in that group.

Therefore, the self-system approach we have discussed at the individual level of analysis can also help explicate the collective efficacy process. Specifically, leaders' and followers' perceptions of the capabilities of the cast of supporting followers, leaders, and peers in their group can be used to inspire each other to accomplish a given collective task. This in turn will heighten those individuals' collective efficacy. This is because collective efficacy is a component of means efficacy (Eden, 2001). Therefore, as shown in Figure 2, given that other forms of efficacy (e.g., thought, self-motivation and action LSE) are also adequately high, collective (means) efficacy may boost overall orchestrated efficacy beliefs when contemplating leader actions.

Moving from the individual level to the collective, Figure 1 indicates that leaders and followers with high levels of efficacy, through their display of efficacious behaviors during social interactions, would signal each other that each can successfully do his or her part in accomplishing group tasks. This is consistent with the findings that both leader and follower efficacies predict collective efficacy (Taggar \& Seijts, 2003).

It is through this emergent process that individual perceptions of collective efficacy can over time form group perceptions of collective efficacy. Kozlowski \& Klein (2000, p. 55) state that "a phenomenon is emergent when it originates in the cognition, affect, behaviors, or other characteristics of individuals, is amplified by their interactions, and manifests as a higher-level, collective phenomenon." Concerning leadership efficacy, over time these individuals would begin to form shared or compatible mental models (Klimoski and Mohammad, 1994; Kozlowski and Klein, 2000) as to the efficacy of the group to influence each other toward increasingly greater levels of performance. Collective leadership efficacy can thus be conceptualized at both the individual, or through the diffusion of shared mental models, at collective levels.

Greater focus is warranted in testing this emergent process as collective efficacy, along with closely related constructs such as group and team efficacies, are well-established as predictors of workgroup outcomes, particularly when team tasks require greater interdependence (Gully et al., 2002). Less attention in this literature has been given to examining the link between leadership and the collective efficacy of teams. However, one well-documented relationship is that more effective leadership styles, particularly transformational leadership, have been repeatedly associated with higher levels of efficacy with individual followers and teams (Arnold et al., 2001; Chen and Lee, 2007; Jung and Sosik, 2003; Kahai et al., 2003; Ross and Gray, 2006; Sivasubramaniam et al., 2002; Walumbwa et al., 2004).

Other aspects of leadership that have also been related to the development of collective efficacy have been reported in the leadership literature. For example, laissez faire leadership style has been shown to be negatively related to collective efficacy in intact teams (Sivasubramaniam et al., 2002). Moreover, Chen \& Bliese (2001) demonstrated that more positive and engaging leadership was associated with higher levels of collective efficacy among followers. Group cohesion 
has also been found to be positively related to higher levels of collective efficacy (Lee, Tinsley, \& Bobko, 2002). Further, while both leader and follower efficacies have been found to influence collective efficacy (Taggar \& Seijts, 2003), Durham, Knight, \& Locke (1997) showed that leader abilities to successfully perform various group tasks, but not follower abilities, predicted the collective efficacy of teams.

In some prior research, collective efficacy has also been shown to be a mediator between leadership style and performance (Ross and Gray, 2006; Sivasubramaniam et al., 2002; Taggar and Seijts, 2003; Walumbwa et al., 2004). These findings supplement the well-established literature linking collective efficacy with group performance outcomes (Chen et al., 2002; Gully et al., 2002; Navon and Erez, 2005; Peterson et al., 2000). Although the pattern of results described here should be viewed as preliminary and requiring further investigation, they can be used to formulate our next set of propositions.

Proposition 8a: Efficacious follower and leader behaviors will predict collective leadership efficacy at both individual and collective levels of analysis.

Proposition 8b: Collective leadership efficacy will promote collective agency, energizing groups and teams to engage and perform to achieve challenging organizational goals.

\subsection{Escalating LSE to cross-level models}

We depict in Figure 1 that the micro and meso processes that build individual and collective leadership efficacy are embedded in and interact with the larger (macro) organizational culture. Based on earlier work by Rousseau (1985) and subsequent work by Klein et al. (1994), as well as more recently by Yammarino et al. (2005), there have been several calls in the leadership literature to examine what have been referred to as cross-level models. This calls for the assessment of the relationship of an independent variable at one level of analysis on dependent variables at the same or subsequent levels of analysis. The independent variable in this instance could be individual or strategic leader efficacy and its multi-level impact on culture, climate and followers' motivation and development (Canella and Monroe, 1997; Boal and Hooijberg, 2001).

Waldman \& Yammarino (1999) have described how leadership at higher or more macro organizational levels can impact subsequent levels using what Bass, Waldman, Avolio \& Bebb (1987) called the "falling dominoes" or "cascading of leadership" impact in organizations. Focusing on transformational leadership, Bass et al. (1987) suggested that such leaders at more senior levels of organizations develop an aggregate leadership style that cascades, resulting in it being represented in similar form at subsequent organizational levels. This process occurs to the degree that such leaders have modeled transformational leadership for subordinate leaders, as well as to the degree transformational leaders have developed their followers to confidently lead in a transformational way.

Bass (1985, p. 47) stated that charismatic transformational leaders, "reciprocate in their confidence in their followers and in their optimistic expectations about their followers' performance. Follower self-esteem and enthusiasm are raised as a consequence and the effort is increased among followers to fulfill the leaders' expressed expectations." We therefore can envision LSE cascading through an organization by the same types of mechanisms that Waldman \& Yammarino (1999) suggest are associated with strategic and transformational leadership.

Offering support for these multi-level effects of leadership, Berson \& Avolio (2004) reported that the strategic leadership of top-level leaders was reflected in subsequent levels of leadership. Specifically, they reported that top-level transformational leaders had subordinate leaders who were more transformational as rated by their followers. Additionally, those subordinate leaders in turn exhibited a more promotion-oriented (and thus likely efficacious) focus in terms of how they then communicated to their own respective followers.

Conversely, Berson \& Avolio (2004) reported that senior leaders, who were evaluated as being more transactional, had followers in subordinate leadership roles that exhibited higher levels of transactional leadership. Moreover, these same transactional leaders reinforced more of a prevention focused strategy in their respective organizational units, which was in turn exhibited via their subordinate leaders' strategic communication messages to their followers.

Waldman \& Yammarino (1999) also suggest that the effects of leadership such as described above can skip levels. Specifically, leader efficacy, messages, and sense of purpose can be communicated down through levels either directly or indirectly demonstrating the kinds of impact that were discussed earlier with respect to the cascading of leadership. To the extent that a more senior leader reinforces a particular message again and again through words, actions and deeds, while also reinforcing others for doing so, we expect that such messages would be transmitted and accepted at subsequent levels of leadership, thereby building leadership efficacy.

Dvir et al. (2002) provided evidence for Waldman \& Yammarino's (1999) assertion showing that platoon commanders who were more transformational impacted the performance and values of their indirect followers two levels down, bypassing squad leaders in terms of direct impact. The impact of the platoon commander was indirect, and may suggest that such leaders create the climate for subordinate leaders and followers to be more efficacious and effective, as we have depicted occurring in Figure 1. We believe this same process might help explain how strategic leaders create the conditions for leaders and followers in their organizations to be both efficacious and effective. However, to date, we know of no research examining these indirect linkages.

In line with examining efficacy at varying organizational levels, we earlier introduced Bandura's (2000) differentiation between personal and collective agency, whereby a leader must have personal agency, as well as be able to exercise his or her agency through collective means. This suggests that leaders can enhance their ability to project their agency and achieve subsequently higher levels of performance in their groups by elevating their group's joint attributions that they can effectively perform their tasks. The process that Bandura has described seems quite similar to the process that Berson 
\& Avolio (2004) described with respect to the cascading effects of transformational leadership. Given that efficacy and agency are inextricably linked (Bandura, 1997), as well as linkages found between efficacy and transformational leadership (e.g. Finn et al., 2007), we propose the next proposition:

Proposition 9: As the more senior leadership in an organization repeatedly achieves successes over time, a collective attribution (i.e., shared mental model) that signals higher organizational efficacy will become part of the organization's culture, thus guiding it to higher levels of collective efficacy, collective agency, and in turn performance.

Another mechanism that can help explain the cascading or diffusion of leadership efficacy involves social networks. Balkundi \& Kilduff (2005, p. 942) summarize the links that form between leadership and social networks stating, "our network approach locates leadership not in the attributes of individuals but in the relationships connecting individuals." Indeed, how leadership is embedded in and contributes to these social networks will determine in part how motivated individuals and larger collectives are to learn, and to perform. For example, a highly efficacious management team that believes it can win in its business and believes it has the means to do so, would be expected to create similarly higher levels of efficacy among their direct followers through means we've described throughout this paper, as well as with their indirect followers through cascading effects across social network linkages.

Many years ago Floyd Allport suggested that groups represent "sets of ideals, thoughts, and habits repeated in each individual mind and existing only in those minds" (1924, p. 9). His position lays the groundwork for considering how shared mental models are developed and how they might facilitate a higher level of collective or organizational efficacy. For example, a shared mental model among top leaders of how to succeed in new and dynamic markets can reinforce similarly shared models in both direct and indirect followers. This type of shared mental model constitutes "a socially constructed understanding of the world derived from social exchanges and interactions among multiple individuals in a group or organization" (Lord \& Emrich, 2001, p. 552). Consequently, we suggest that what we've described at the individual or follower level in terms of what constitutes leader efficacy, can now be considered at the group or organizational level as being a shared belief for the collective confidence of an organization to perform.

In sum, we have noted above that efficacy is a self-concept based phenomenon (Bandura, 1997) and that accumulating evidence suggests that leaders can alter the self-concepts of followers either directly or as we have shown through indirect means (e.g., [Ibarra, 1999; Gardner and Avolio, 1998; Lord and Brown, 2004; Lord et al., 1999). We also know that leaders can raise followers' efficacy through contagion-like effects (Bono and Ilies, 2006; Cherulnik et al., 2001), and that the leadership influence process is bidirectional where followers also influence the self-concept of their leader (e.g., [Dvir and Shamir, 2003; Gardner and Avolio, 1998; Lord et al., 1999; Shamir et al., 1993). Thus we submit it is impossible to examine the leadership influence process without examining the mechanisms that influence leader and follower efficacies at multiple levels of analysis.

\subsection{Implications of LSE at multiple levels}

To the degree that the senior leadership of an organization has higher self, collective and means efficacies, we would expect followers at subsequent levels to be more likely to attribute greater trust in their leaders and each other's commitment and capabilities, thus increasing levels of collective and organizational efficacy. Over time, these collectives would enhance an organizational climate and culture that promotes and simultaneously sustains efficacy at both individual and collective levels as depicted in Figure 1.

One factor underlying the process of development is what Dweck (1989) referred to as having a learning versus performance goal orientation. Individuals that have a learning goal orientation would be more likely to view their ability to take on tasks as incremental and malleable. These individuals view feedback as contributing to their development (Button, Matieu, \& Zajac, 1996).

Although Dweck and others have discussed learning goal orientation at an individual level, we believe, similar to the process we have discussed linking leader efficacy to leadership efficacy, that one can examine the development of a group or organization's learning goal orientation climate and how it might impact the collective overall organizational efficacy. Indeed, to refer to an organization as a 'learning organization' (Argyris and Schon, 1978; Nonaka, 1994) infers that such organizations have a collective learning goal orientation.

Hannah \& Lester (in press) specifically theorize how leaders create learning organizations by developing individuals with high levels of learning efficacy and learning goal orientation (what they call 'knowledge catalysts') and then they set the conditions for these catalysts to operate across social networks to create and diffuse knowledge. We suggest a similar process for developing highly efficacious leaders and followers who interact to diffuse their efficacy, thereby sustaining and reinforcing LSE within and between levels of analysis.

Efficacious organizations would tend to place trust in and sponsor the autonomy, competence and relatedness of its leaders and associates (Ryan \& Deci, 2003). For example, such trust could be expressed in tangible ways as resource allocations, empowering policies, and adaptive systems - all actions that have been shown to increase means efficacy (Eden, 2001). Further, trust among leaders' and followers' capabilities might promote greater levels of shared leadership within and between organizational levels (Pearce, 2004). Ensley, Hmieleski, \& Pearce (2006, p. 218) define shared leadership as a "mutual influence process within a team that is characterized by 'serial emergence' of official as well as unofficial leaders." Such shared leadership could be viewed as another facilitating mechanism for promoting collective organizational efficacy (Edmondson, 1999). 
In sum, we believe there is sufficient evidence to justify that the construct of efficacy can be elevated beyond the group (meso) level and diffused to the organizational (macro) level (Alavi, 2005; Lindsley et al., 1995). In particular, we propose that efficacy might become part of a shared mental model, conceptualized as patterns of overlapping knowledge or beliefs across individuals that a given collective holds (Cannon-Bowers et al., 1990; Klimoski and Mohammad, 1994). This leads to our tenth proposition:

Proposition 10: An efficacious organizational climate and/or culture will be conducive to the development of leadership efficacy at individual (micro) and collective (meso) levels, ultimately sustaining higher organizational (macro) levels of efficacy.

\section{Application to practice: strategies for developing leader efficacy}

Up to this point, we have primarily attempted to explain the mechanisms associated with LSE at multiple levels of analysis. Now in this last section we turn our attention back to individual leader efficacy and focus on development. Thus, we close out discussion of Figure 1 by explaining the developmental processes that build leaders' psychological resources to engage with their followers and group, thereby over time building collective leadership efficacy. One can also extrapolate from this discussion principles that can apply to both follower and group efficacy development.

Since there is such limited work on leader efficacy in general, it is not surprising that there is so little published (Finn et al., 2007; McCormick, 1999; Mellor et al., 2006) work on developing efficacy beliefs in leaders. Mellor et al. (2006) demonstrated that efficacy beliefs for union members were positively associated with encouragement by leaders. Finn et al. (2007) showed that long-term feedback and executive training was associated not only with increased leader efficacy, but also leadership performance. During a series of interventions lasting over 5 weeks, Hannah (2006) raised levels of generalized leader efficacy through mastery experiences, social persuasion, and guided reflection; that in turn predicted motivation to lead (Chan \& Drasgow, 2001), transformational leadership (Bass, 1985) and performance over a 34-week span. However, it has been noted that LSE itself is highly stable over time and some prior research has failed to find developmental effects for shorter interventions (McCormick, 1999).

Given the central role of LSE in the formation of individual and collective agency and performance, there clearly seems to be a need for increased research on the methods and conditions under which LSE can be more or less effectively developed. To this point, there has been relatively little work done on potential individual differences that may have interacted with leader efficacy to impact the results reported above, as well as the task dynamics.

\subsection{Leader efficacy development techniques}

Outside the field of leadership, techniques for building efficacy have been well tested in prior research. These efficacy development techniques include mastery experiences, vicarious learning, social persuasion, and arousal (Bandura, 1997), as well as raising the salience and perceived utility of means available to complete the task (Eden, 2001). Bandura (1997) states that the most potent antecedents to the creation of efficacy beliefs are mastery experiences based on past performance accomplishments. Indeed, prior leadership experiences have been found to predict leader efficacy (McCormick et al., 2002). However, Bandura (1997) is also careful to point out that success alone does not equal efficacy, but rather how the individual interprets the success (e.g., was it earned through ability and effort).

Leader efficacy may also be developed through modeling or vicarious learning where individuals observe competent and relevant models successfully performing similar tasks, building LSE through cascading or contagion effects as discussed earlier. The amount of influence of vicarious observations is based on the level of similarity between the model and the observer on characteristics that are relevant to the task, and the similarity of the observed task and the task presently faced by the individual (Bandura, 1997; Stajkovic and Luthans, 1998).

Bandura's (1997) recommendation for the impact of persuasion and positive feedback is a third way that leader efficacy may be developed (see [Berson et al., 2001; Garland and Adkinson, 1987). Mellor et al. (2006), for example, showed that persuasion raised LSE to take on leadership roles. However, the impact of persuasive information has been shown to vary based on factors such as credibility, expertness, and consensus (Bandura, 1997).

A fourth widely recognized way to develop self-efficacy is psychological, physiological and emotional arousal (Bandura, 1997). However, sources of arousal can be perceived as either positive or negative by the target leader. Some leaders may find some indicators of arousal to be energizing, while others may see them as signs of vulnerability or stress, and associate such stress with a lack of confidence (Bandura, 1997). Supporting this claim, Wood \& Bandura (1989a) found that managers with higher self-efficacy beliefs experience less depression when faced with threatening situations.

Concerning the means component of the proposed LSE construct, Eden (2001) proposes that raising levels of means efficacy can be achieved by enhancing an individual's perception of the quality and utility of tools (e.g., people, policies, equipment, and resources) available for the task, and the applicability of those tools to the setting/context. Importantly, it is not the tool itself, but the person's assessment or belief in the quality and utility of the tools to performing the task at hand that contributes to one's level of means efficacy.

Eden \& Sulimani (2002) were able to boost means efficacy through raising followers' expectations of the quality of their equipment for a particular task. Specifically, they randomized groups to conditions and in those conditions where experimenters raised participant beliefs about the quality of the equipment available to perform actual tasks, those groups performed significantly better on those tasks. The beliefs that Eden manipulated had nothing to do with the actual quality of 
the equipment, since the equipment was identical across the experimental conditions. This preliminary body of research leads to our next proposition:

Proposition 11: LSE being state-like can be developed for positive impact on performance through role modeling, vicarious learning, persuasion, arousal, raising the salience and perceived utility of leadership means, and focused mastery training interventions.

\subsection{Applying the self-system to leader efficacy development}

In addition to the widely recognized sources of efficacy development, based on the previous discussion, we propose that leader efficacy development may also entail changing leaders' self-concepts to incorporate the various forms of efficacy across a broader set of leadership roles (Hannah et al., in press; Kihlstrom et al., 1994; Lord and Brown, 2004). Drawing from Frederickson's work in positive psychology (Fredrickson, 2001; Fredrickson et al., 2003), developing personal resources that establish positive states may promote flourishing, positive affectivity, and broadening of thought repertoires when leaders are faced with challenging and stressful tasks. These resources could be expected to result in greater levels of leader positivity and adaptability when facing not just stressful situations, but leadership challenges in general.

Fredrickson and her colleagues showed that such higher levels of positivity led to greater levels of inquiry in groups confronting problems (Fredrickson and Losada, 2005; Losada and Heaphy, 2004). The link between increasing positivity in leaders and their groups of followers, and how openly they confront problems by searching for what each other knows, may in part help explain how leader positivity and efficacy may drive follower and collective efficacy in groups.

Extrapolating from the work above, we suggest that future research could assess leader efficacy development as an individualized construction developed over the life span. This development occurs as leaders interpret and encode their life experiences into the social role structures contained in their self-concept as outlined earlier, and can later on selectively draw on those experiences and the skills they engendered to enhance their efficacy (Hannah and Luthans, 2008; Lord and Hall, 2005; Kihlstrom et al., 1994; Shamir and Eilam, 2005). Kihlstrom et al. (1994) call such collections of selfefficacy and other self-evaluative beliefs meta-knowledge that can be accessed through declarative processes to impact future behaviors. The development of this meta-knowledge may help explain how generalized leader efficacy impacts more role-specific efficacy over time.

\subsubsection{The influence of developmental readiness}

Based on our earlier suggestion that leader efficacy interacts within the self-system, it follows that other self-relevant individual difference constructs may impact leader efficacy development and promote the overall growth of leaders and followers. In their model of developmental readiness, Avolio \& Hannah (in press) propose that efficacy beliefs interact with self-awareness and goal orientation, as well as meta-cognitive ability and self-complexity to accelerate development. We focus on two of those constructs here. Specifically, in addition to learning efficacy as presented earlier, the individual differences of goal orientation and self-awareness might be fruitful areas to explore when examining the acceleration of leader efficacy development. For instance, Kanfer (1990) suggested that the individual difference of goal orientation may be a key predictor of self-efficacy development. Phillips \& Gully (1997) found that learning goal orientation was positively related to levels of self-efficacy, while performance goal orientation was negatively related. Schmidt \& Ford (2003) replicated this finding and additionally found a positive relationship between the individual differences of mastery orientation and meta-cognitive ability with higher levels of self-efficacy. Further, we suggest that the level of self-awareness or clarity that leaders have over their self-concept (Campbell, Assanand, \& Di Paula, 2003) will influence their ability to both develop their efficacy and later call forth their efficacy when faced with leadership challenges.

It must be remembered that leaders' efficacy beliefs are perceptions of and can thus be distinct from their actual capabilities, just as self-efficacy beliefs are distinct from means efficacy. Leaders' efficacy involves their perception both of their capabilities and how those capabilities can be used in a given task and context. Therefore, we suggest that the efficacy beliefs of highly self-aware leaders will be based on realistic assessments of their actual capabilities, or what Bandura (1997) calls 'efficacy calibration', where calibration helps the leader to identify areas for needed skill development (Lord \& Hall, 2005). Thus, a useful future area of research would be to investigate the effects of self-reflection and awareness on such efficacy calibration, and the subsequent effects on leaders' under or overconfidence taking into consideration the context in which those calibrations are developed.

Another crucial question to ask in terms of leader efficacy development is whether leaders are sufficiently self-aware enough to self-reflect in an adaptive manner, or if they engage in rumination, which could retard the development of LSE. Along these lines, Avolio, Wernsing, Chan \& Griffith (2007) distinguish between two forms of self-reflection that are relevant to understanding the development of leader self-efficacy: adaptive and maladaptive. Adaptive self-reflection is defined as being a constructive process of reflection associated with patterns of thinking and emotions characterized by openness, positivity, and a learning perspective (Trapnell \& Campbell, 1999). Self-regulation theorists argue that openness to aspects of the self can result in greater self-awareness and self-knowledge that contributes to more effective self-regulation over time (Carver \& Scheier, 1982). In contrast, maladaptive self-reflection involves more destructive ways of thinking that generates negative emotions such as anxiety, self-doubt, and fear-based actions (Mor \& Winquist, 2002), which could diminish one's thought efficacy, self-motivation and ultimately performance.

Whether leaders choose to engage in adaptive versus maladaptive reflection is affected by how they are primed by situational factors. Prior research has shown that it is relatively easy to elicit maladaptive reflection through instruc- 
tions that ask participants to focus on the "things that went wrong" with a situation (e.g., Watkins \& Teasdale, 2004). Rumination involves a repetitive re-examining of an issue coupled with higher levels of resistance and negative judgment (Nolen-Hoeksema, 1991), resulting in a leader hoping the situation is not real and therefore not adapting to the situation. Rumination is maladaptive because it uses up cognitive resources that could have otherwise been applied to problem solving and development (Teasdale, 1999). When leaders focus too much on what is wrong with the situation versus trying to adapt, they likely will diminish their own efficacy as well as those they lead. This leads to our last research proposition:

Proposition 12: The level of leader developmental readiness (i.e. learning goal orientation and self-awareness) and methods of reflection will impact the development of LSE, through self-concept changes, in both leaders and followers, and in turn will impact their respective performance.

\subsubsection{A cycle of positive development}

Finally, we propose that future research should investigate leader efficacy development as a cycle of positive development. Research has shown that those with higher levels of self-efficacy (Krueger \& Dickson, 1993) and general efficacy (Betz and Hacket, 1986; Lent and Hackett, 1987) focus on opportunities to pursue challenges, while those with lower efficacy focus on risks to be avoided. We propose that through their approach orientation, leaders with higher efficacy will increase their exposure to developmental events and experience a continuous widening (generalization) of their domain of leader efficacy over time, as we inferred above with respect to invoking adaptive self-reflection. Further, Silver, Mitchell, \& Gist (1991) found that individuals with high and low self-efficacy both attributed success to their own abilities. However, when unsuccessful, those with high levels of efficacy attributed failures to inadequate effort, or bad luck. On the other hand, those with low efficacy attributed failure to a lack of ability, which may further reduce their future levels of efficacy, and in turn deleteriously affect their future performance. On the other hand, a cycle of positive development of leader efficacy may result in upward spiraling of efficacy and sustainable performance impact.

\section{Some final thoughts}

The overriding purpose of this review was not only to identify and analyze the existing limited literature on leader efficacy, but also to bring into focus a more expanded, dynamic view of what constitutes leadership efficacy and its development at multiple levels of analysis. In particular, our aim was to define this expanded view of leadership efficacy and propose how it can impact across a broad range of organizational contexts, performance criteria, and domains of interest. We have chosen this focus based on the fact that the efficacy construct is perhaps one of the most validated constructs in the behavioral sciences, yet has been given relatively little attention in leadership theory and research. By building on such a strong conceptual and empirical foundation, our intent was to stimulate and advance leadership efficacy research with individuals, teams and organizations.

Through investigating leadership efficacy as a multivariate and multi-level construct, we believe it is possible to focus development in a more refined manner to advance positive cognitions, affects, goals and values, expectancies and selfregulatory mechanisms in leaders, their followers, and the groups they lead. Leaders who are oriented toward growth and engagement in challenges are more likely to bring about these same outcomes in those they lead. We believe a robust conceptualization of leadership efficacy as presented here can contribute to not only a better understanding of effective leadership, but also help answer the call for informed insights into the intrapersonal processes related to leadership skill development and use (Lord \& Hall, 2005), and overall leadership development (Day, 2001).

To conclude, as the field of leadership development moves forward by building interventions based on well tested theory, we expect that focusing on leadership self-efficacy (LSE) will enhance the impact of such interventions on leader and follower development. By integrating the work on LSE and leadership development across levels of organizations, we also advance the prospect that changes in leadership efficacy will likely have a better chance of sustainability. Specifically, to the degree that both leader and follower efficacy are enhanced, and in turn the collective efficacy of the group they belong to is also enhanced, we would expect that leadership interventions will have more positive and sustainable effects across organizational levels.

\section{Acknowledgments}

The authors pay their greatest respects to Professor Jerry Hunt, a friend, colleague and icon of the leadership field. Jerry's impact on the advancement of leadership theory and research has been extensive and his legacy will live on in those like us he has influenced. We also want to thank Dr. Hunt and two anonymous reviewers for The Leadership Quarterly for their insights and guidance in improving this manuscript.

\section{References}

ABelson, 1981 - R. P. Abelson, The psychological status of the script concept, American Psychologist 36 (7) (1981), pp. 715-729.

Alavi, 2005 - S. B. Alavi (2005). "A multilevel approach to studying collective efficacy in organizational change." Paper presented at the Tehran International Management Conference, Tehran, Iran.

AlLPORT, 1924 - F. H. Allport, Social psychology, Houghton Mifflin, Boston (1924).

ARGYRIS AND SCHON, 1978 - C. Argyris and D. Schon, Organizational learning, Addison Wesley, Reading, Mass. (1978). 
ARNoLD ET AL. , 2001 - K. Arnold, J. Barling and E. Kelloway, Transformational leadership or the iron cage: Which predicts trust, commitment, and team efficacy, The Leadership and Organization Development Journal 22 (2001), pp. 315-320.

Avolio, 2002 - B. J. Avolio, Examining the full range model of leadership: Looking back to transform forward. In: D. Day and S. Zaccarro, Editors, Leadership development for transforming organizations, Erlbaum, Mahwah, NJ (2002).

Avolio, 2005 - B. J. Avolio, Leadership in balance: Made/Born, Erlbaum, NJ (2005).

Avolio and Hannah, In Press - B. J. Avolio and S. T. Hannah (in press). Developmental readiness: Accelerating leader development. Consulting Psychology Journal.

Avolio And Luthans, 2006 - B. Avolio and F. Luthans, The high impact leader, McGraw-Hill, New York (2006).

Avolio ET AL. , 2007 - B. J. Avolio, T. Wernsing, A. Chan, and J. Griffith (2007). "A theory of developing leader self awareness. " Unpublished manuscript, University of Nebraska-Lincoln.

BalKundi And Kilduff, 2005 - P. Balkundi and M. Kilduff, The ties that lead: A social network approach to leadership, The Leadership Quarterly 16 (2005), pp. $941-961$.

BANDURA, 1989 - A. Bandura, Regulation of cognitive processes through perceived self-efficacy, Developmental Psychology 25 (5) (1989), pp. $729-735$.

BANDURA, 1997 - A. Bandura, Self-efficacy: The exercise of control, Freeman, New York (1997).

BAndura, 1999 - A. Bandura, A social cognitive theory of personality. In: L. Pervin and O. John, Editors, Handbook of personality (2nd ed. ), Guilford Publications, New York (1999), pp. 154-196.

BANDURA, 2000 - A. Bandura, Exercise of human agency through collective efficacy, Current Directions in Psychological Science 9 (3) (2000), pp. 75-78.

BANDURA, 2001 - A. Bandura, Social cognitive theory: An agentic perspective, Annual Review of Psychology 52 (2001), pp. 1-26.

BANDURA AND LoCKE, 2003 - A. Bandura and E. A. Locke, Negative self-efficacy and goal effects revisited, Journal of Applied Psychology 88 (2003), pp. 87-99.

BANDURA AND WOOD, 1989 - A. Bandura and R. Wood, Effect of perceived controllability and performance standards on self-regulation of complex decision making, Journal of Personality and Social Psychology 56 (1989), pp. 805-814.

BAss, 1985 - B. M. Bass, Leadership and performance beyond expectations, Free Press, New York (1985).

BAss And Avolio, 1997 - B. M. Bass and B. J. Avolio, Full range leadership development: Manual for the Multifactor Leadership Questionnaire, Mindgarden, Palo Alto, CA (1997).

BAss ET AL. , 1987 - B. M. Bass, D. A. Waldman, B. J. Avolio and M. Bebb, Transformational leaders: The falling dominoes effect, Group and Organization Studies 12 (1987), pp. 73-87.

BenNIS AND NANus, 1985 - W. Bennis and B. Nanus, Leaders: the strategies for taking charge, Harper \& Row, New York (1985).

BerRY, 1987 - J. M. Berry (1987). "A self-efficacy model of memory performance. " Paper presented at the 95th annual convention of the American Psychological Association, New York.

BERRY, 1989 - J. M. Berry, Reliability and validity of the memory self-efficacy questionnaire, Developmental Psychology 25 (1989), pp. 701-713.

Berson And Avolio, 2004 - Y. Berson and B. Avolio, Transformational leadership and the dissemination of organizational goals: A case study of a telecommunication firm, The Leadership Quarterly 15 (2004), pp. 625-646.

BERSON ET AL. , 2001 - Y. Berson, B. Shamir, B. J. Avolio and M. Popper, The relationship between vision, strength, leadership style, and context, The Leadership Quarterly 12 (2001), pp. 53-73.

BEtZ AND HACKET, 1986 - N. E. Betz and G. Hacket, Applications of self-efficacy theory to understanding career choice behavior, Journal of Social and Clinical Psychology 4 (1986), pp. 279-289.

BOAL AND HoOIJBERG, 2001 - K. B. Boal and R. Hooijberg, Strategic leadership research: Moving on, The Leadership Quarterly 11 (2001), pp. 515-549.

BONO AND Ilies, 2006 - J. E. Bono and R. Ilies, Charisma, positive emotions and mood contagion, The Leadership Quarterly 17 (2006), pp. $317-334$.

Button ET AL. , 1996 - S. B. Button, J. E. Matieu and D. M. Zajac, Goal orientation in organizational research: A conceptual and empirical foundation, Organizational Behavior and Human Decision Processes 67 (1996), pp. 26-48.

ButLER, 1993 - R. Butler, Effects of task and ego achievement goals on information-seeking during task engagement, Journal of Personality and Social Psychology 65 (1993), pp. $18-31$.

CAmEron AND CAZA, 2004 - K. S. Cameron and A. Caza, Contributions to the discipline of positive organizational scholarship, American Behavioral Scientist, 476 (2004), pp. 1-9.

CAMERon ET AL. , 2003 - K. S. Cameron, J. E. Dutton and R. E. Quinn, Editors, Positive organizational psychology: foundations of a new discipline, Berrett-Koehler Publishers, San Francisco, CA (2003).

Campbell et AL. , 2003 - J. D. Campbell, S. Assanand and A. Di Paula, The structure of the self-concept and its relation to psychological adjustment, Journal of Personality 71 (2003), pp. 115-140.

Canella and Monroe, 1997 - A. A. Canella Jr. and M. J. Monroe, Contrasting perspectives on strategic leaders: Toward a more realistic view of top managers, Journal of Management 23 (1997), pp. 213-237.

CANNON-Bowers ET AL. , 1990 - J. A. Cannon-Bowers, E. Salas and S. A. Converse, Cognitive psychology and team training: Shared mental models in complex systems, Human Factors Bulletin 33 (1990), pp. 1-4.

CARroll and BANDURA, 1987 - W. R. Carroll and A. Bandura, Translating cognition into action: The role of visual guidance in observational learning, Journal of Motor Behavior 19 (1987), pp. 385-398.

CARVER AND SCHEIER, 1982 - C. S. Carver and M. F. Scheier, Control theory: A useful conceptual framework for personality-social, clinical, and health psychology, Psychological Bulletin 92 (1982), pp. 111-135

CARVER AND SCHEIER, 1998 - C. S. Carver and M. F. Scheier, On the self-regulation of behavior, Cambridge University Press, New York (1998),

Chan And Drasgow, 2001 - K. Y. Chan and F. Drasgow, Toward a theory of individual differences and leadership: Understanding the motivation to lead, Journal of Applied Psychology 86 (3) (2001), pp. 481-498.

CHEMERS, 1997 - M. M. Chemers, An integrative theory of leadership, Lawrence Erlbaum, Hillsdale, NJ (1997).

Chemers et AL. , 2000 - M. M. Chemers, C. B. Watson and S. T. May, Dispositional affect and leadership effectiveness: A comparison of self-esteem, optimism, and efficacy, Personality and Social Psychology Bulletin 26 (2000), pp. 267-277.

CHEN AND BLIese, 2001 - G. Chen and P. Bliese, The role of different levels of leadership in predicting self- and collective efficacy: Evidence for discontinuity, Journal of Applied Psychology 87 (2001), pp. 549-556.

CHEN ET AL. , 2001 - G. Chen, S. M. Gully and D. Eden, Validation of a new general self-efficacy scale, Organizational Research Methods 4 (1) (2001), pp. $62-83$.

CHEN AND LeE, 2007 - C. Chen and H. Lee, Effects of transformational team leadership on collective efficacy and team performance, International Journal of Management and Enterprise Development 4 (2007), pp. 202-217.

CHEN ET AL. , 2002 - G. Chen, S. Webber, P. Bliese, J. Mathieu, S. Payne and D. Born et al. , Simultaneous examination of the antecedents and consequences of efficacy beliefs at multiple levels of analysis, Human Performance 15 (2002), pp. 381-409.

Cherulnik ET AL. , 2001 - P. D. Cherulnik, K. A. Donley, T. S. R. Weiwel and S. R. Miller, Charisma is contagious: The effects of leaders' charisma on follower affect, Journal of Applied Social Psychology 31 (2001), pp. 2149-2159.

Conway, 2000 - J. M. Conway, Managerial performance development constructs and personality correlates, Human Performance 13 (2000), pp. $23-46$.

Cropanzano et al. , 1993 - R. Cropanzano, K. James and M. Citera, A goal hierarchy model of personality, motivation, and leadership, Research in Organizational Behavior 15 (1993), pp. 267-322.

DAY, 2001 - D. V. Day, Leadership development: A review in context, The Leadership Quarterly 11 (2001), pp. 581-614.

Dennison $E T$ AL. , 1995 - D. R. Dennison, R. Hooijberg and R. E. Quinn, Paradox and performance: Toward a theory of behavioral complexity in managerial leadership, Organizational Science 6 (1995), pp. 524-540.

DeShon AND GILlespie, 2005 - R. P. DeShon and J. Z. Gillespie, A motivated action theory account of goal orientation, Journal of Applied Psychology 90 (2005), pp. 1096-1127.

DurHAm ET AL. , 1997 - C. Durham, D. Knight and E. Locke, Effects of leader role, team-set goal difficulty, efficacy, and tactics on team effectiveness, Organizational Behavior and Human Decision Processes 72 (1997), pp. 203-231.

Dvir ET AL. , 2002 - T. Dvir, D. Eden, B. J. Avolio and B. Shamir, Impact of transformational leadership training on follower development and performance: A field experiment, Academy of Management Journal 45 (2002), pp. 735-744.

Dvir AND SHAmir, 2003 - T. Dvir and B. Shamir, Follower developmental characteristics as predicting transformational leadership: A longitudinal field study, The Leadership Quarterly 14 (2003), pp. 327-344.

DWECK, 1989 - C. S. Dweck, Motivation. In: A. Lesgold and R. Glaser, Editors, Foundations for a psychology of education, Lawrence Erlbaum, Hillsdale, NJ (1989).

DwECK ET AL. , 2003 - C. S. Dweck, E. T. Higgins and H. Grant-Pillow, Self-systems give unique meaning to self variables. In: M. Leary and J. P. Tangney, Editors, Handbook of self and identity, Guilford Press, New York, NY (2003), pp. 239-252.

EDEN, 1992 - D. Eden, Leadership and expectations: Pygmalion effects and other self-fulfilling prophecies in organizations, The Leadership Quarterly 3 (1992), pp. 271-305.

EDEN, 1996 - D. Eden (1996, August). "From self-efficacy to means efficacy: Internal and external sources of general and specific efficacy. " Paper presented at the 56th Annual Meeting of the Academy of Management, Cincinnati, $\mathrm{OH}$ 
EDEN, 2001 - D. Eden, Means efficacy: External sources of general and specific subjective efficacy. In: M. Erez, U. Kleinbeck and H. Thierry, Editors, Work motivation in the context of a globalizing economy, Lawrence Erlbaum, Hillsdale, NJ (2001), pp. 65-77.

Eden AND Sulimani, 2002 - D. Eden and R. Sulimani, Pygmalion training made effective: Greater mastery through augmentation of self-efficacy and means efficacy. In: B. J. Avolio and F. J. Yammarino, Editors, Transformational/charismatic leadership: The road ahead, Elsevier, New York (2002).

EDmondson, 1999 - A. Edmondson, Psychological safety and learning behavior in work teams, Administrative Science Quarterly 44 (1999), pp. 350-383.

ENSLEY ET AL. , 2006 - M. D. Ensley, K. M. Hmieleski and C. L. Pearce, The importance of vertical and shared leadership within new venture top management teams: Implications for the performance of startups, The Leadership Quarterly 17 (2006), pp. 217-231.

FINN ET AL. , 2007 - F. Finn, C. Mason, and L. Bradley (2007). “Doing well with executive coaching: Psychological and behavioral impacts. " Paper presented at the Academy of Management Conference, Philadelphia.

Fredrickson, 2001 - B. L. Fredrickson, The role of positive emotions in positive psychology: The broaden-and-build theory of positive emotions, American Psychologist 56 (2001), pp. 218-226.

Fredrickson And Losada, 2005 - B. L. Fredrickson and M. F. Losada, Positive affect and the complex dynamics of human flourishing, American Psychologist 60 (2005), pp. 678-686.

Fredrickson $E T$ AL. , 2003 - B. L. Fredrickson, M. M. Tugade, C. E. Waugh and G. R. Larkin, What good are positive emotions in crises? A prospective study of resilience and emotions following the terrorist attacks on the United States on Sept 11th, 2001, Journal of Personality and Social Psychology 84 (2003), pp. 365-376.

GarLAND And AdKInson, 1987 - H. Garland and J. H. Adkinson, Standards, persuasion, and performance: A test of cognitive mediation theory, Group E Organizational Studies 12 (1987), pp. 208-220.

Gardner and Avolio, 1998 - W. I. Gardner and B. J. Avolio, The charismatic relationship: A dramaturgical perspective, Academy of Management Review 23 (1998), pp. $32-58$.

George, 2003 - W. George, Authentic leadership: Rediscovering the secrets to creating lasting value, Jossey-Bass, San Francisco (2003).

Giola AND Poole, 1984 - D. A. Gioia and P. P. Poole, Scripts in organizational behavior, Academy of Management Review 9 (1984), pp. 449-459.

GIST, 1989 - M. E. Gist, The influence of training method on self-efficacy and idea generation among managers, Personnel Psychology 42 (1989), pp. 787-805.

Gist And Mitchell, 1992 - M. E. Gist and T. R. Mitchell, Self-efficacy: A theoretical analysis of its determinants and malleability, Academy of Management Review 17 (1992), pp. $183-211$.

GOLDBERG, 1993 - L. R. Goldberg, The structure of phenotypic personality traits, American Psychologist 48 (1993), pp. 26-34.

GulLY ET AL. , 2002 - S. M. Gully, K. A. Incalcaterra, A. Joshi and J. M. Beaubien, A meta-analysis of team efficacy, potency and performance: Interdependence and level of analysis as moderators of observed relationships, Journal of Applied Psychology 87 (2002), pp. 819-832.

Graen and UhL-BiEn, 1995 - G. B. Graen and M. Uhl-Bien, Relationship-based approach to leadership: Development of leader-member exchange (LMX) theory of leadership over 25 years: Applying a multi-level multi-domain perspective, Leadership Quarterly 6 (1995), pp. 219-247.

Hannah, 2006 - S. T. Hannah (2006). Agentic leadership efficacy: Test of a new construct and model for development and performance. Unpublished doctoral dissertation. University of Nebraska-Lincoln.

HANNAH ET AL. , 2008 - S. T. Hannah, J. T. Eggers, and P. L. Jennings, Complex adaptive leadership. In: G. B. Graen and J. A. Graen, Editors, Knowledge driven corporation: a discontinuous model, LMX leadership: The series, Vol. VI, Information Age Publishing Inc. , Charlotte, NC (2008)

HANNAH AND LESTER, IN PRESS - S. T. Hannah and P. Lester (in press). A multilevel approach to building and leading learning organizations. The Leadership Quarterly.

HANNAH AND Luthans, 2008 - S. T. Hannah and F. Luthans, A cognitive affective processing explanation of positive leadership: Toward theoretical understanding of the role of psychological capital. In: R. H. Humphrey, Editor, Affect and emotion: new directions in management theory and research, volume 7 of research in management, Information Age Publishing (2008)

HANNAH ET AL. , IN PRESS - S. T. Hannah, L. Woolfolk, and R. Lord (in press). Leader self-structure: A framework for positive leadership. Journal of Organizational Behavior.

Hendricks And PAYne, 2007 - J. Hendricks and S. Payne, Beyond the big five: Leader goal orientation as a predictor of leadership effectiveness, Human Performance 20 (2007), pp. $317-343$.

HigGins ET AL. , 1998 - E. T. Higgins, E. Van Hook, and D. Dorfman, Do self-attributes form a cognitive structure?, Social Cognition 6 (1998), pp. 177-206.

HoLDEN, 1991 - G. Holden, The relationship of self-efficacy appraisals and subsequent health related outcomes: A meta-analysis, Social Work Health Care 16 (1991), pp. 53-93.

HogG, 2001 - M. A. Hogg, A social identity theory of leadership, Personality and Social Psychology Review 5 (2001), pp. 184-200.

Hollenbeck And Hall, 2004 - G. P. Hollenbeck and D. T. Hall, Self-confidence and leader performance, Organizational Dynamics 33 (2004), pp. $254-269$.

HooIjBERG ET AL. , 1997 - R. Hooijberg, J. G. Hunt, and G. E. Dodge, Leadership complexity and development of the leaderplex model, Journal of Management 23 (3) (1997), pp. 375-408.

House, 1996 - R. J. House, Path-goal theory of leadership: Lessons, legacy, and a reformulated theory, Leadership Quarterly 7 (1996), pp. 323-352.

House AND AditYA, 1997 - R. J. House and R. N. Aditya, The social scientific study of leadership: Quo vadis?, Journal of Management 23 (1997), pp. 409-473.

Howell AND SHAmir, 2005 - J. M. Howell and B. Shamir, The role of followers in the charismatic leadership process: Relationships and their consequences, Academy of Management Review 30 (2005), pp. 96-112.

Hoyt, 2005 - C. Hoyt, The role of leadership efficacy and stereotype activation in women's identification with leadership, Journal of Leadership \& Organizational Studies 11 (2005), pp. 2-14.

Hoyt And Blascovich, 2003 - C. Hoyt and J. Blascovich, Transformational and transactional leadership in virtual and physical environments, Small Group Research 34 (2003), pp. 678-715.

Hoyt ET AL. , 2003 - C. Hoyt, S. Murphy, S. Halverson, and C. Watson, Group leadership: Efficacy and effectiveness, Group Dynamics: Theory, Research, and Practice 7 (2003), pp. $259-274$.

Hultsch ET AL. , 1988 - D. F. Hultsch, C. Hertzog, R. A. Dixon, and H. Davidson In: M. L. Howe and C. J. Brainerd, Editors, Cognitive development in adulthood: progress in cognitive development research, Springer, New York (1988), pp. 65-92.

Hunt, 2005 - J. R. Hunt, The leadership quarterly yearly review of leadership. In: J. R. Hunt, Editor, The Leadership Quarterly 16 (2005), pp. 873-1006.

Hunt, 2006 - J. R. Hunt, The leadership quarterly yearly review of leadership. In: J. R. Hunt, Editor, The Leadership Quarterly 17 (2006), pp. 555-690.

Hunt AND Phillips, 1991 - J. G. Hunt and R. L. Phillips, Leadership in battle and garrison: A framework for understanding the differences and preparing for both. In: R. Gal and D. Mangeldorrf, Editors, Handbook of military psychology, Wiley, Chichester, UK (1991), pp. 411-429.

IвARRA, 1999 - H. Ibarra, Provisional selves: Experimenting with image and identity in professional adaptation, Administrative Science Quarterly 44 (1999), pp. 764-791.

JENKINS, 1994 - A. Jenkins, The role of managerial self-efficacy in corporate compliance with the law, Law and Human Behavior 18 (1994), pp. 71-88,

Johnson ET AL. , 2006 - R. E. Johnson, D. Chang, and R. G. Lord, Moving from cognition to behavior: What the research says, Psychological Bulletin 132 (2006), pp. $381-415$.

Judge ET AL. , 2003 - T. A. Judge, A. Erez, J. E. Bono, and C. J. Thoresen, The core self-evaluations scale: Development of a measure, Personnel Psychology 56 (2003), pp. $303-331$.

Judge ET AL. , 1997 - T. A. Judge, E. A. Locke, and C. C. Durham, The dispositional causes of job satisfaction: A core evaluations approach, Research in Organizational Behavior 19 (1997), pp. 151-188.

JUNG AND SoSIK, 2003 - D. Jung and J. Sosik, Group potency and collective efficacy, Group Organization Management 28 (2003), pp. 366-391.

KAHAI ET AL. , 2003 - S. Kahai, J. Sosik, and B. Avolio, Effects of anonymity, rewards, and leadership style in an electronic meeting system context, The Leadership Quarterly 14 (2003), pp. 499-524.

Kane ET AL. , 2002 - T. D. Kane, S. J. Zaccaro, T. R. Tremble, and A. D. Masuda, An examination of the leader's regulation of groups, Small Group Research 33 (2002), pp. 65-120.

KANFER, 1987 - R. Kanfer, Task-specific motivation: An integrative approach to issues of measurement, mechanisms, processes, and determinants, Journal of Social and Clinical Psychology 5 (1987), pp. 237-264.

KANFER, 1990 - R. Kanfer, Motivation and individual differences in learning: An integration of development, differential and cognitive perspectives, Learning and Individual Differences 2 (1990), pp. 221-239.

KANFer And AcKerman, 1989 - R. Kanfer and P. L. Ackerman, Motivation and cognitive abilities: An integrative/aptitude-treatment interaction approach to skill acquisition, Journal of Applied Psychology 74 (1989), pp. 657-689.

KAPLAN, 1991 - R. E. Kaplan, Beyond ambition: how driven managers can lead better and live better, Jossey-Bass, San Fransciso (1991).

KARK AND Shamir, $2002-$ R. Kark and B. Shamir, The dual effect of transformational leadership: Priming relational and collective selves and further effects on followers. In: B. J. Avolio and F. J. Yammarino, Editors, Transformational and charismatic leadership: The road ahead, Vol. 2, JAI Press, Amsterdam (2002), pp. 67-91.

KARK ET AL. , 2003 - R. Kark, B. Shamir and G. Chen, The two faces of transformational leadership: Empowerment and dependency, Journal of Applied Psychology 88 (2003), pp. $246-255$

KAzDIN, 1978 - A. E. Kazdin, Covert modeling-Therapeutic application of imagined rehearsal. In: J. L. Singer and K. S. Pope, Editors, The power of human imagination: new methods in psychotherapy. Emotions, personality, and psychotherapy, Plenum, New York (1978), pp. 255-278.

KIHLSTROM ET AL. , 1994 - J. F. Kihlstrom, J. S. Beer, and S. B. Klein, Self and identity as memory. In: M. R. Leary and J. P. Tangney, Editors, Handbook of self and identity, Guilford Press, New York, NY (1994), pp. 68-90 
KIRKPATRICK AND LOCKE, 1996 - S. Kirkpatrick and E. A. Locke, Direct and indirect effects of three core charismatic leadership components on performance and attitudes, Journal of Applied Psychology 8 (1996), pp. 36-51.

KLEIN ET AL. , 1994 - K. J. Klein, F. Dansereau, and R. J. Hall, Levels issues in theory development, data collection and analysis, Academy of Management Review 19 (1994), pp. 195-229.

Klimoski and Mohammad, 1994 - R. Klimoski and S. Mohammad, Team mental model: Construct or metaphor?, Journal of Management 20 (1994), pp. $403-437$.

KozLOWSKI AND KLEIN, 2000 - S. W. J. Kozlowski and K. J. Klein, A multilevel approach to theory and research in organizations: Contextual, temporal, and emergent processes. In: K. J. Klein and S. W. J. Kozlowski, Editors, Multilevel theory, research, and methods in organizations, Jossey-Bass, San Franscisco (2000), pp. 3-90.

Kouzes And Posner, 1993 - J. M. Kouzes and B. Z. Posner, Credibility: How leaders gain and lose it, why people demand it, Jossey-Bass, San Francisco (1993).

Krueger and Dickson, 1993 - N. F. Krueger Jr. and P. R. Dickson, Self-efficacy and perceptions of opportunities and threats, Psychological Reports 72 (1993), pp. 1235-1240.

LARSON AND BORGEN, 2006 - L. Larson and F. Borgen, Do personality traits contribute to vocational self-efficacy?, Journal of Career Assessment 14 (2006), pp. $295-311$.

LeE ET AL. , 2002 - C. Lee, C. Tinsley and P. Bobko, An investigation of the antecedents and consequences of group-level confidence, Journal of Applied Social Psychology 32 (2002), pp. $1628-1652$.

Lent AND HACKeTt, 1987 - R. W. Lent and G. Hackett, Career self-efficacy: Empirical status and future directions, Journal of Vocational Behavior 30 (1987), pp. $347-382$.

LiNDSLEY ET AL. , 1995 - H. Lindsley, D. J. Brass and J. B. Thomas, Efficacy-performance spirals: A multi-level perspective, Academy of Management Review 20 (1995), pp. 645-678.

Linville, 1987 - P. W. Linville, Self-complexity as a cognitive buffer against stress-related illness and depression, Journal of Personality and Social Psychology 52 (1987), pp. 663-676.

LOCKE, 1991 - E. A. Locke, The essence of leadership: the four keys to leading successfully, Lexington Books, New York (1991).

LoGAN AND KLAPP, 1991 - G. D. Logan and S. T. Klapp, Automatizing alphabet arithmetic I: Is extended practice necessary to produce automaticity?, Journal of Experimental Psychology: Learning, Memory, and Cognition 17 (1991), pp. 179-195.

LORD AND BROWN, 2004 - R. G. Lord and D. J. Brown, Leadership processes and follower self-identity, Lawrence Erlbaum, New Jersey (2004).

LoRD ET AL. , 1999 - R. G. Lord, D. J. Brown, and S. J. Freiberg, Understanding the dynamics of leadership: The role of follower self-concepts in the leader/follower relationship, Organizational Behavior and Human Decision Processes 78 (1999), pp. 167-203.

LORD AND EMrICH, 2001 - R. G. Lord and C. G. Emrich, Thinking outside the box by looking inside the box: Extending the cognitive revolution in leadership research, The Leadership Quarterly 11 (4) (2001), pp. 551-579.

LoRD AND HALL, 2005 - R. G. Lord and R. J. Hall, Identity, deep structure and the development of leadership skills, Leadership Quarterly 16 (2005), pp. $591-615$.

LORD ET AL. , 1984 - R. G. Lord, R. J. Foti, and C. L. DeVader, A test of leadership categorization theory: Internal structure, information processing, and leadership perceptions, Organizational Behavior and Human Performance 34 (1984), pp. 343-378.

Losada And HeapHy, 2004 - M. Losada and E. Heaphy, The role of positivity and connectivity in the performance of business teams, American Behavioral Scientist 47 (2004), pp. $740-765$.

LuTHANS, 2002 - F. Luthans, The need for and meaning of positive organizational behavior, Journal of Organizational Behavior 23 (2002), pp. 695-706.

Luthans AND Avolio, 2003 - F. Luthans and B. J. Avolio, Authentic leadership: A positive developmental approach. In: K. S. Cameron, J. E. Dutton and R. E. Quinn, Editors, Positive organizational scholarship, Berrett-Koehler, San Francisco (2003), pp. 241-258.

Luthans et AL. , 2007 - F. Luthans, B. J. Avolio, J. B. Avey and S. M. Norman, Positive psychological capital: Measurement and relationship with performance and satisfaction, Personnel Psychology 60 (2007), pp. 541-572.

Luthans ET AL. , 2002 - F. Luthans, K. W. Luthans, R. M. Hodgetts and B. C. Luthans, Positive approach to leadership, The Journal of Leadership Studies 8 (2002), pp. 3-20.

LuthANS AND PETERSon, 2002 - F. Luthans and S. J. Peterson, Employee engagement and manager self-efficacy: Implications for managerial effectiveness and development, Journal of Management Development 21 (5) (2002), pp. 376-387.

LutHANS AND YousseF, 2007 - F. Luthans and C. Youssef, Emerging positive leadership behavior, Journal of Management 33 (2007), pp. 321-349.

Luthans et AL. , 2007 - F. Luthans, C. M. Youssef, and B. J. Avolio, Psychological capital, Oxford University Press, New York (2007).

Lyons AND Murphy, 1994 - Lyons, C. \& Murphy, M. (1994). “Principal self-efficacy and the use of power." Paper presented at the American Educational Research Association, New Orleans, LA.

Maddux, 1995 - J. E. Maddux, Editor, Self-efficacy, adaptation, and adjustment: theory, research, and application, Plenum, New York (1995).

Manz, 1986 - C. C. Manz, Self-leadership: Toward and expanded theory of self-influence processes in organizations, Academy of Management Review 11 (1986), pp. 585-600.

Marion AND UhL-BIEN, 2001 - R. Marion and M. Uhl-Bien, Leadership in complex organizations, Leadership Quarterly 12 (2001), pp. $389-418$.

Marion And UhL-Bien, 2007 - R. Marion and M. Uhl-Bien, Complexity and strategic leadership. In: R. Hooijberg, J. Hunt, K. Boal and J. Antonakis, Editors, Being there even when you are not: Leading through strategy, structures, and systems, Monographs in Leadership and Management, Vol. 4, Elsevier, Amsterdam (2007), pp. 273-287.

Markus AND WURF, 1987 - H. Markus and E. Wurf, The dynamic self-concept: A psychological perspective, Annual Review of Psychology 38 (1987), pp. $299-337$.

MARSH AND SHAVELSON, 1985 - H. Marsh and R. Shavelson, Self-concept: Its multifaceted, hierarchical structure, Educational Psychologist 20 (1985), pp. 107-123.

MсСовміск, 1999 - M. J. McCormick (1999). The Influence of goal orientation and sex-role identity on the development of leadership self-efficacy during a training intervention. Unpublished dissertation, Texas A\&M.

MсСовміск, 2001 - M. J. McCormick, Self-efficacy and leadership effectiveness: Applying social cognitive theory to leadership, Journal of Leadership Studies 8 (2001), pp. 22-33.

McCormick ET AL. , 2002 - M. J. McCormick, J. Tanguma, and A. S. Lopex-Forment, Extending self-efficacy theory to leadership: A review and empirical test, Journal of Leadership Education 1 (2002), pp. 34-49.

MelLor ET AL. , 2006 - S. Mellor, L. Barclay, C. Bulger, and L. Kath, Augmenting the effect of verbal persuasion on self-efficacy to serve as a steward: Gender similarity in a union environment, Journal of Occupational and Organizational Psychology 79 (2006), pp. 121-129.

MINER, 1993 - J. B. Miner, Role motivation theories, Routledge, London (1993).

Mischel AND SHODA, 1998 - W. Mischel and Y. Shoda, Reconciling processing dynamics and personality dispositions, Annual Review of Psychology 49 (1998), pp. 229-258.

Mor AND WINQUisT, 2002 - N. Mor and J. Winquist, Self-focused attention and negative affect: A meta-analysis, Psychological Bulletin 128 (2002), pp. 638-662.

Mumford and Connelly, 1991 - M. D. Mumford and M. S. Connelly, Leaders as creators: Leader performance and problem solving in ill-defined domains, The Leadership Quarterly 2 (1991), pp. 289-316.

Mumford ET AL. , 2007 - M. D. Mumford, T. L. Friedrich, J. J. Caughron and C. L. Byrne, Leader cognition in real-world settings: How do leaders think about crisis?, The Leadership Quarterly 18 (2007), pp. 515-543.

Multon ET AL. , 1991 - K. D. Multon, S. D. Brown and R. W. Lent, Relation of self-efficacy beliefs to academic outcomes: A meta-analytic investigation, Journal of Counseling Psychology 38 (1991), pp. 30-38

MURPHY AND ENSHER, 1999 - S. Murphy and E. Ensher, The effects of leaders and subordinate characteristics in the development of leader-member exchange quality, Journal of Applied Social Psychology 29 (1999), pp. 1371-1394.

NAIDOO AND LORD, 2008 - L. J. Naidoo and R. G. Lord, Speech imagery and perceptions of charisma: The mediating role of positive affect, The Leadership Quarterly 19 (2008), pp. 283-296.

NAVON AND EREz, 2005 - T. Navon and M. Erez, When collective- and self-efficacy affect team performance, Small Group Research 36 (2005), pp. 437-465.

Nolen-HoeKsema, 1991 - S. Nolen-Hoeksema, Responses to depression and their effects on the duration of depressive episodes, Journal of Abnormal Psychology 100 (1991), pp. 569-582

NONAKA, 1994 - I. Nonaka, A dynamic theory of organizational knowledge creation, Organization Science 5 (1994), pp. 14-37.

OngLatco ET AL. , 1993 - M. Onglatco, E. Yuen, C. Leong, and G. Lee, Managerial self-efficacy and managerial success in Singapore, International Journal of Management 10 (1993), pp. $14-21$.

Osborn ET AL. , 2002 - R. N. Osborn, J. R. Hunt, and L. R. Jauch, Toward a contextual theory of leadership, The Leadership Quarterly 13 (2002), pp. 797-837.

PAGLIS, 1999 - L. Paglis (1999). Searching for the wellspring of leading change: Leader self-efficacy in organizations. Unpublished doctoral dissertation. Purdue University.

Paglis and Green, 2002 - L. L. Paglis and S. G. Green, Leadership self-efficacy and managers' motivation for leading change, Journal of Organizational Behavior 23 (2002), pp. $215-235$.

PARRY, 1998 - K. Parry, The new leader: A synthesis of leadership research in Australia and New Zealand, Journal of Leadership Studies 5 (1998), pp. 82-105.

Pearce, 2004 - C. L. Pearce, The future of leadership: Combining vertical and shared leadership to transform knowledge work, Academy of Management Executive 18 (2004), pp. $47-57$

Peterson Et AL. , 2000 - E. Peterson, T. Mitchell, L. Thompson, and R. Burr, Collective efficacy and aspects of shared mental models as predictors of performance over time in work groups, Group Processes and Intergroup Relations 3 (2000), pp. 296-316.

PHILLIPs, 2000 - J. Phillips, The role of decision influence and team performance in member self-efficacy, withdrawal, satisfaction with the leader, and willingness to return, Organizational Behavior and Human Decision Processes 84 (2000), pp. 122-147.

PhilliPs And Gully, 1997 - J. M. Phillips and S. M. Gully, Role of goal orientation, ability, need of achievement, and locus of control in the self-efficacy and goal-setting process, Journal of Applied Psychology 82 (1997), pp. 792-802 
Pillai And Williams, 2004 - R. Pillai and E. Williams, Transformational leadership, self-efficacy, group cohesiveness, commitment, and performance, Journal of Organizational Change Management 17 (2004), pp. 144-159.

Porter and McLaughtin, 2006 - L. W. Porter and G. B. McLaughlin, Leadership and the organizational context: Like the weather, The Leadership Quarterly 17 (2006), pp. 559-576.

Popper ET AL. , 2004 - M. Popper, K. Amit, R. Gal, M. Mishkal-Sinai, and A. Lisak, The capacity to lead: Major psychological differences between leaders and nonleaders, Military Psychology 16 (2004), pp. 245-263.

Prussia ET AL. , 1998 - G. E. Prussia, J. S. Anderson, and C. C. Manz, Self-leadership and performance outcomes: The mediating influence of self-efficacy, Journal of Organizational Behavior 19 (1998), pp. 523-538.

Prussia And Kinicki, 1996 - G. E. Prussia and A. Kinicki, A motivational investigation of group effectiveness using social-cognitive theory, Journal of Applied Psychology 81 (1996), pp. 187-198.

QuiNN, 1988 - R. E. Quinn, Beyond rational management: mastering the paradoxes and competing demands of high performance, Jossey-Bass, San Francisco (1988).

RAFFERTY AND GRIFFIN, 2006 - A. Rafferty and M. Griffin, Refining individualized consideration: Distinguishing development and supportive leadership, Journal of Occupational and Organizational Psychology 79 (2006), pp. 37-61.

ROBERTSON AND SADRI, 1993 - I. T. Robertson and G. Sadri, Managerial self-efficacy and managerial performance, British Journal of Management 4 (1993), pp. $37-45$.

Ross AND GRAY, 2006 - J. Ross and P. Gray, Transformational leadership and teacher commitment to organizational values: The mediating effects of collective teacher efficacy, School Effectiveness and School Improvement 17 (2006), pp. 179-199.

ROusseAu, 1985 - D. M. Rousseau, Issues of level in organizational research: Multi-level and cross-level perspectives, Research in Organizational Behavior 7 (1985), pp. 1-38.

RYAN AND DECI, 2003 - R. M. Ryan and E. L. Deci, On assimilating identities to the self: A self-determination theory perspective on internalization and integrity within cultures. In: M. R. Leary and J. P. Tangney, Editors, Handbook of self and identity, Guilford, New York (2003), pp. 253-272.

SCHANK AND ABELSON, 1977 - R. C. Schank and R. P. Abelson, Scripts, plans, goals and understanding: an inquiry into human knowledge structures, Hillsdale NJ, Erlbaum (1977).

SCHMIDT AND FORD, 2003 - A. M. Schmidt and K. J. Ford, Learning within a learner control training environment: The interactive effects of goal orientation and metacognitive instruction on learning outcomes, Personnel Psychology 56 (2003), pp. 405-429.

Schunk AND GunN, 1986 - D. H. Schunk and T. P. Gunn, Self-efficacy and skill development: Influence of task strategies and attributions, Journal of Educational Research 79 (1986), pp. 238-244.

SCHRUIJER AND VANSINA, 2002 - S. Schruijer and L. Vansina, Leader, leadership and leading: from individual characteristics to relating in context, Journal of Organizational Behavior 23 (2002), pp. 869-874.

Semandar et al. , 2006 - A. Semandar, G. Robins, and G. Ferris, Comparing the validity of multiple social effectiveness constructs in the prediction of managerial job performance, Journal of Organizational Behavior 27 (2006), pp. 443-461.

Shamir and EILAm, 2005 - B. Shamir and G. Eilam, "What's your story?” A life-stories approach to authentic leadership development, The Leadership Quarterly 16 (2005), pp. 395-417.

SHAmir ET AL. , 1993 - B. Shamir, R. J. House, and M. Arthur, The motivational effects of charismatic leadership: A self-concept based theory, Organizational Science 4 (1993), pp. $1-17$.

SHAMIR ET AL. , 1996 - B. Shamir, E. Zakay, E. Breinin and M. Popper, Correlates of charismatic leader behavior in military units: Subordinates' attitudes, unit characteristics, and superiors' appraisals of leader performance, Academy of Management Journal 41 (1996), pp. 387-409.

Shavelson ET AL. , 1976 - R. Shavelson, J. Hubner, and G. Stanton, Self-concept: Validation of construct interpretations, Review of Educational Research 46 (1976), pp. 407-441.

SHEA AND HowelL, 1999 - C. Shea and J. Howell, Charismatic leadership and task feedback: A laboratory study of their effects on self-efficacy and task performance, The Leadership Quarterly 10 (1999), pp. 375-396.

SHODA ET AL. , 2002 - Y. Shoda, S. LeeTiernan and W. Mischel, Personality as a dynamical system: Emergence of stability and distinctiveness from intra- and interpersonal interactions, Personality and Social Psychology Review 6 (2002), pp. 316-325.

SILVER ET AL. , 1991 - W. S. Silver, T. R. Mitchell, and M. E. Gist (1991). "Interpreting performance information: The influence of self-efficacy on causal attributions for successful and unsuccessful performance. " Unpublished manuscript, University of Washington, Seattle.

SINGER, 1989 - M. Singer, Individual differences in leadership aspirations: An exploratory study from valence, self-efficacy and attribution perspectives, Journal of Social Behavior and Personality 3 (1989), pp. 253-262.

SINGER, 1991 - M. Singer, The relationship between employee sex, length of service, and leadership aspirations: A study from valence, self-efficacy, and attribution perspectives, Applied Psychology: An International Review 40 (1991), pp. 417-436.

Sivasubramaniam Et AL. , 2002 - N. Sivasubramaniam, W. Murry, B. Avolio, and D. Jung, A longitudinal model of the effects of team leadership and group potency on group performance, Group and Organization Management 27 (2002), pp. 66-96.

SPELKE ET AL. , 1976 - E. Spelke, W. Hirst, and U. Neisser, Skills of divided attention, Cognition 4 (1976), pp. 215-230.

StAJKovic and Luthans, 1998 - A. D. Stajkovic and F. Luthans, Self-efficacy and work-related performance: A meta analysis, Psychological Bulletin 124 (1998), pp. 240-261.

TAGGAR AND SeIJT, 2003 - S. Taggar and G. H. Seijts, Leader and staff role-efficacy as antecedents of collective-efficacy and team performance, Human Performance 16 (2003), pp. $131-156$

TASA ET AL. , 2007 - K. Tasa, S. Taggar and G. H. Seijts, The development of collective efficacy in teams: A multilevel and longitudinal perspective, Journal of Applied Psychology 92 (2007), pp. 17-27

TeASDALE, 1999 - J. Teasdale, Emotional processing, three modes of the mind, and the prevention of relapse in depression, Behaviour Research and Therapy 37 (1999), pp. S53-S77.

Trapnell and CAmpbell, 1999 - P. D. Trapnell and J. D. Campbell, Private self-consciousness and the five-factor model of personality: Distinguishing rumination from reflection Journal of Personality \& Social Psychology 76 (1999), pp. 284-304

VAN KNIPPENBERG ET AL. , 2004 - D. van Knippenberg, B. van Knippenberg, D. De Cremer and M. A. Hogg, Leadership, self, and identity: A review and research agenda, The Leadership Quarterly 15 (2004), pp. 825-856.

VandeWalle et Al. , 2001 - D. VandeWalle, W. L. Cron and J. W. Slocum, The role of goal orientation following performance feedback, Journal of Applied Psychology 86 (2001), pp. 629-640.

VARGAS-Tonsing ET AL. , 2003 - T. Vargas-Tonsing, A. Warners and D. Feltz, The predictability of coaching efficacy on team efficacy and player efficacy in volleyball, Journal of Sport Behavior 26 (2003), pp. 396-407.

Waldman and Yammarino, 1999 - D. A. Waldman and F. J. Yammarino, CEO charismatic leadership: Levels of management and levels of analysis, Academy of Management Review 24 (1999), pp. 266-285.

WalumbWa et AL. , 2008 - F. Walumbwa, B. Avolio, and W. Zhu (in press). How transformational leadership weaves its influence on individual job performance: The role of identification and efficacy beliefs, Personnel Psychology 61 (2008), pp. 793-825

WalumbWa et AL. , 2004 - F. Walumbwa, P. Wang, J. Lawler and K. Shi, The role of collective efficacy in the relations between transformational leadership and work outcomes, Journal of Organizational and Occupational Psychology 77 (2004), pp. 515-553.

WatKins AND TeasDale, 2004 - E. Watkins and J. D. Teasdale, Adaptive and maladaptive self-focus in depression, Journal of Affective Disorders 82 (2004), pp. 1-8.

Watson ET AL. , 2001 - C. Watson, M. Chemers and N. Preiser, Collective efficacy: A multilevel analysis, Personality and Social Psychology Bulletin 27 (2001), pp. 1057-1068.

WooD, 2007 - D. Wood, Using PRISM to compare the explanatory value of general and role-contextualized trait ratings, Journal of Personality 75 (2007), pp. 1103-1126.

WOOD AND BANDURA, 1989A - R. E. Wood and A. Bandura, Impact of conceptions of ability on self-regulatory mechanisms and complex decision making, Journal of Personality and Social Psychology 56 (1989), pp. 407-415

WOOD AND BANDURA, 1989B - R. E. Wood and A. Bandura, Social cognitive theory of organizational management, Academy of Management Review 14 (1989), pp. 361-384.

Wooford AND Goodwin, 1994 - J. C. Wooford and V. L. Goodwin, A cognitive interpretation of transactional and transformational leadership theories, Leadership Quarterly 5 (1994), pp. 161-186.

WOOFORD ET AL. , 1998 - J. C. Wooford, V. L. Goodwin and J. L. Whittington, A field study of a cognitive approach to understanding transformational and transactional leadership, Leadership Quarterly 9 (1998), pp. 55-84.

WoolfolK ET AL. , 2004 - R. L. Woolfolk, M. A. Gara, L. A. Allen and J. D. Beaver, Self-complexity: An assessment of construct validity, Journal of Social and Clinical Psychology 23 (2004), pp. 463-474.

YAMmARINO ET AL. , 2005 - F. J. Yammarino, S. D. Dionne, J. U. Chun and F. Dansereau, Leadership and levels of analysis: A state-of-the-science review, The Leadership Quarterly 16(2005), pp. 879-919.

YUKL, 2002 - G. Yukl, Leadership in organizations (5th ed. ), Prentice-Hall, Upper Saddle Creek, NJ (2002).

Yukl and Van Fleet, 1992 - G. Yukl and D. D. Van Fleet, Theory and research on leadership in organizations. In: M. D. Dunnette and L. M. Hough, Editors (2nd ed. ), Handbook of Industrial and Organizational Psychology, Vol. 3, CPP, Palo Alto, CA (1992), pp. 147-197.

ZBrodoff AND Logan, 1986 - N. J. Zbrodoff and G. D. Logan, On the autonomy of mental processes: A case study of arithmetic, Journal of Experimental Psychology: General 115 (1986), pp. 118-130. 